\title{
MATTHEW WEBB
}

\section{A Common Market Problem Becomes More Common: the Trans- \\ Tasman Proceedings Act 2010}

Laws 525: International Commercial Contracts

Final Paper (February 2015)

\section{FACULTY OF LAW}

TE WHARE WĀNANGA O TE ŪPOKO O TE IKA A MĀUI

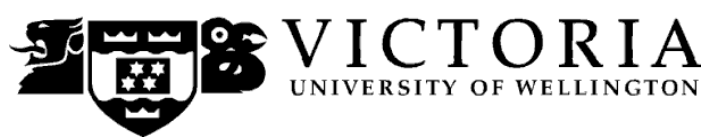

2014 


\section{Abstract}

As part of a wider process of economic integration and the move towards a single integrated economic market, Australia and New Zealand entered into bi-lateral treaty in 2008 in order to resolve existing issues with the reciprocal enforcement of civil judgment which had arisen between the two countries. Labelled the "Christchurch Agreement" this treaty was incorporated by both countries into their domestic law in 2010 and now governs the allocation of disputes between Australia and New Zealand, where the parties are located within the common market of Australia and New Zealand and inter-state enforcement of civil judgments more generally. The Trans-Tasman Proceedings Act 2010 (Cth) and (NZ) ("TTPA"), will arguably provide significant benefits by reducing barriers to trade and improving the economic prosperity of both countries. However it is argued that, similar to other common market reciprocal enforcement schemes (such as the Brussels Model in the European Union), Australia and New Zealand failed to consider the impact of the outer world problem. The outer world problem is a recurring theme in common market arrangements, and results from a failure to provide generic proportionate jurisdictional test for cases involving foreign defendants sued in a common market state. The result is excessive jurisdictional rules within a particular state can potentially result in proceedings being retained where there is a strong argument the dispute is more closely connected with another forum. The resulting judgment (should judgment in the plaintiff's favour be granted), can then be quickly enforced throughout the common market (specifically New Zealand) to the disadvantage of the defendant. The outer world problem is clearly present under the TTPA scheme, beginning in Australia and cumulating in enforcement of the judgment in New Zealand. It remains present even in the case of international commercial contract disputes. This is unfair and discriminatory towards foreign defendants, and arguably justifies reform, or at least discussion and justification of this approach.

Keywords: private international law, Trans-Tasman Proceedings Act 2010, outer world problem, jurisdiction, enforcement of foreign judgments 
Table of Contents

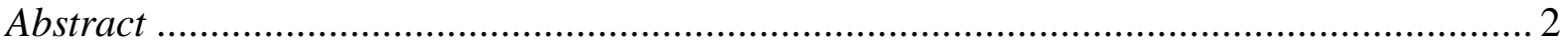

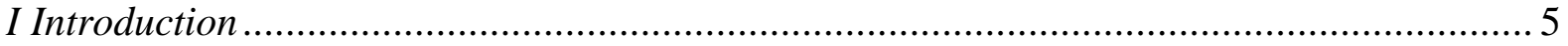

A Presence of the Outer World Problem under the TTPA …........................................ 5

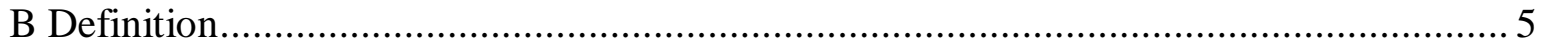

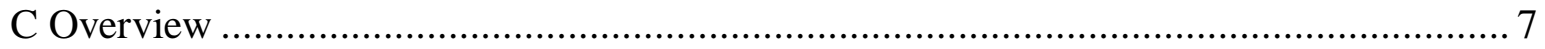

D Outer World Problem and Commercial Contract Disputes......................................... 8

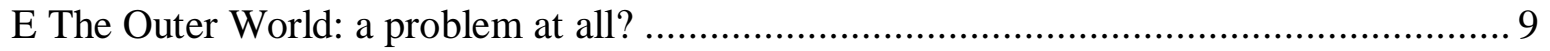

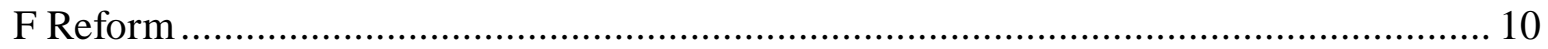

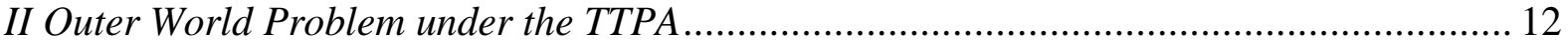

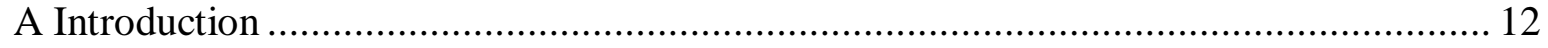

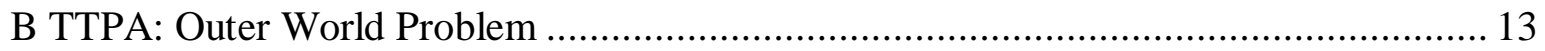

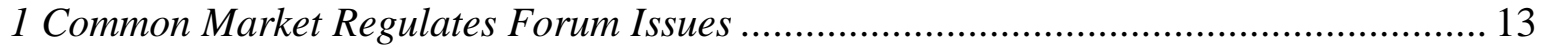

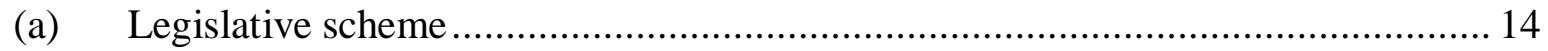

2 Common market fails to regulate forum issues for foreign defendant .......................... 17

3 Domestic Private International Law of Australia is Biased ....................................... 19

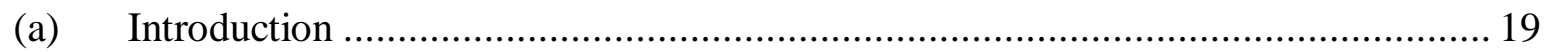

(b) Forum Non Conveniens ...................................................................................... 20

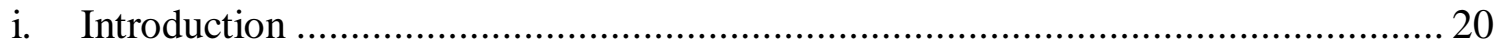

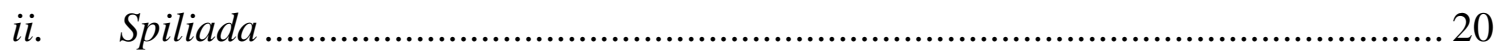

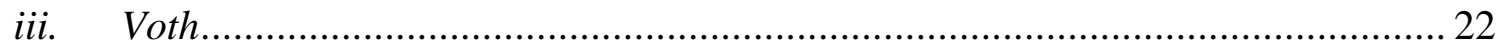

iv. Trans-Tasman Proceedings Act 2010 (Cth), s 19 .......................................... 23

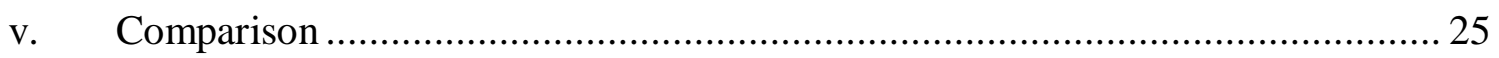

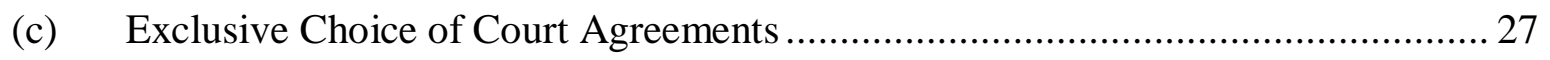

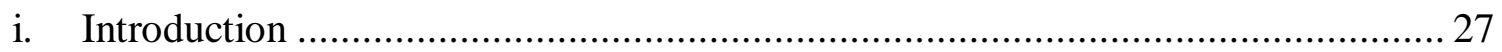

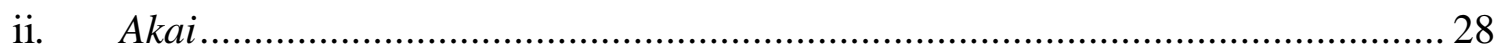

iii. Bias Under Exclusive Choice of Court Agreements ........................................ 29

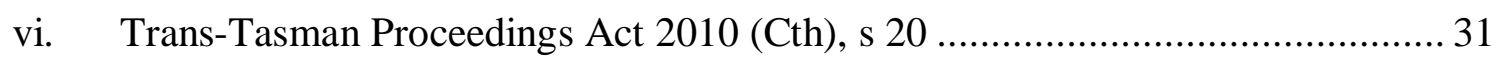

v. Outer World Problem and Exclusive Choice of Court Agreements .................... 33

(b) Non-exclusive Choice of Court Agreements....................................................... 36

4 Streamlined Reciprocal Enforcement Regime........................................................ 37

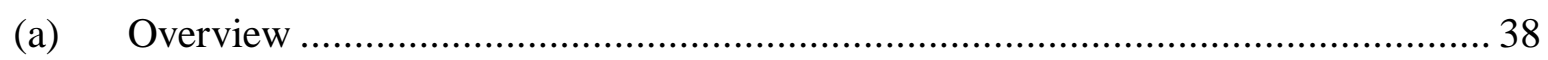

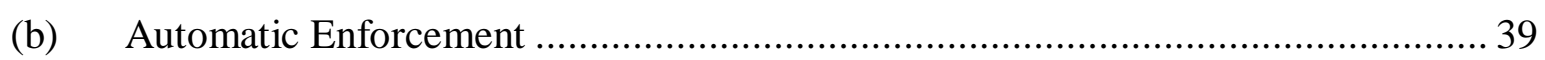

III The Outer World Problem: A Problem at All? ............................................................... 42 


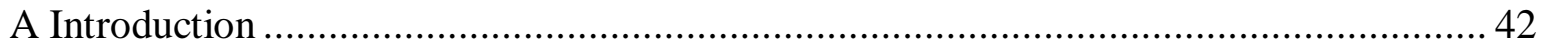

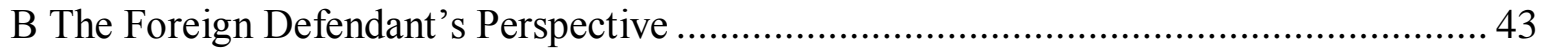

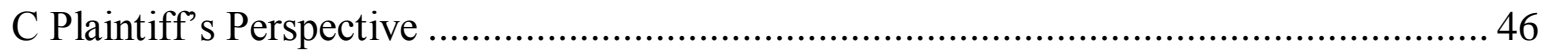

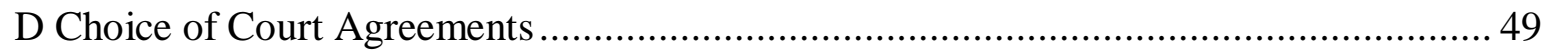

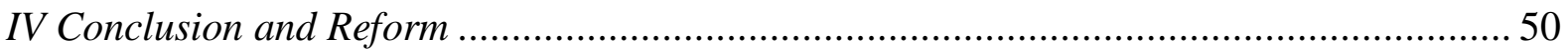

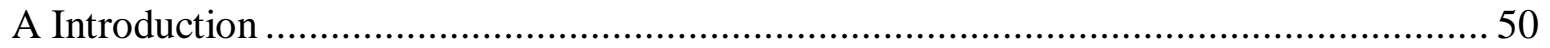

B Amend the Trans-Tasman Proceedings Act 2010 (Cth), s 19 ..................................... 51

C Realign the Private International Law of Australia and New Zealand .......................... 52

D Remove Judgments Against Foreign Defendants from the TTPA .............................. 54

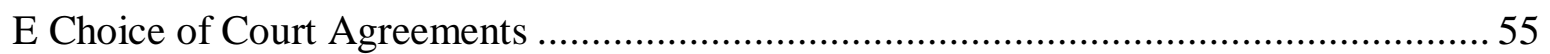

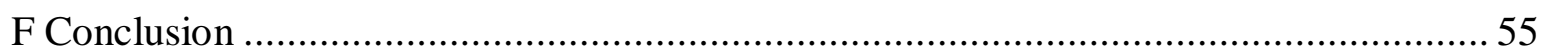

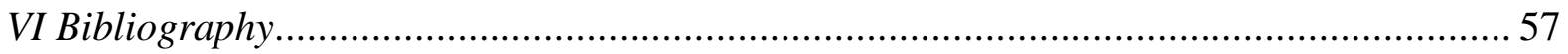

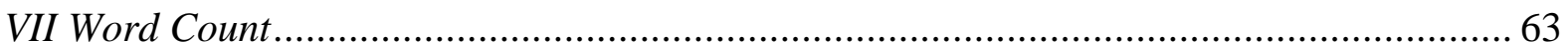




\section{Introduction}

A Presence of the Outer World Problem under the TTPA

One of the fundamental precepts of the common law has been to ensure that disputes are resolved in a manner where both (or all) parties are treated in a fair and even handed manner by the legal system tasked with resolving their dispute. ${ }^{1}$ Legislation which favours a particular party in a dispute (or is discriminatory in the sense that it legally treats one party differently to the other based on their nationality or race) should be based on sound and coherent reasoning. This criterion provides a useful sounding board when scrutinising the significant changes which have come about in relation to the reciprocal enforcement of foreign judgments across both sides of the Tasman. ${ }^{2}$ In late 2013 the Trans-Tasman Proceedings Act 2010 (NZ) came into force in New Zealand and marks a significant departure from the abovementioned principle. ${ }^{3}$ In particular the reciprocal enforcement regime established by the TTPA is, from the defendant's perspective "nothing short of scandalous" because of the "harsh and discriminatory treatment" of defendants located outside of the common market. ${ }^{4}$ The impetus for the TTPA was giving force to a bilateral agreement entered into between New Zealand and Australia in 2008 as part of a wider process to remedy issues with the then existing judgment enforcement regime between the two nations. ${ }^{5}$ Mirror incorporating legislation has been passed in Australia in order to give effect to the Christchurch Agreement. ${ }^{6}$ The issues with the TTPA scheme have arguably arisen as a result of the outer world problem.

\section{B Definition}

\footnotetext{
${ }^{1}$ See Black $v$ Taylor [1993] 3 NZLR 403 (CA). at 408-409 per Richardson J; "The right to a fair hearing in the Courts is an elementary but fundamental principle of British justice. It reflects the historical insistence of the common law that disputes be settled in a fair, open and even-handed way (emphasis added)."

${ }^{2}$ For an overview of these changes see Reid Mortensen "A Trans-Tasman Judicial Area: Civil Jurisdiction and Judgments in the Single Economic Market” (2010) 16 Canta LR 61.

${ }^{3}$ Trans-Tasman Proceedings Act 2010 (NZ). For the mirror Australian incorporating legislation see the TransTasman Proceedings Act 2010 (Cth) (the "TTPA" collectively unless referred to otherwise).

${ }^{4}$ A Briggs and P Rees Civil Jurisdiction and Judgments (2nd ed, LLP, 1997) at 311.

${ }^{5}$ Agreement between the Government of Australia and the Government of New Zealand on Trans-Tasman Court Proceedings and Regulatory Enforcement (done at Christchurch 24 July 2008) ("Christchurch Agreement"). For a useful overview of other issues the Christchurch Agreement was intended to remedy see Mortensen above n 2, at 61-65.

${ }^{6}$ See footnote 3 .
} 
The "outer world" problem is not-a new one with respect to common market arrangements. Mortensen notes that similar issues have arisen in the context of the single market of the European Union, ${ }^{7}$ and have been subject to vehement academic criticism as far back as the original inception of the Brussels Convention in 1968. ${ }^{8}$ Unsurprisingly the outer world problem involves outer world judgments. Outer world judgments are judgments made by a court which have extra-territorial effect, by determining the liability (or absence thereof) of a foreign subject. ${ }^{9}$

The problem of outer world judgments arises under a reciprocal judgment enforcement regime within a common market area, where there is no curtailment of domestic-based jurisdictional laws or rules. This allows market area courts to exercise excessive jurisdiction with respect to defendants located outside of the common market, subject to that forums private international law rules. ${ }^{10}$ Under such regimes, there will be limits placed on the ability of the plaintiff to have proceedings against other parties within the market area resolved in whatever state they choose. ${ }^{11} \quad$ No such protection is offered to foreign defendants - any domestic statute (or Court rules-based) conferred jurisdiction (no matter how exorbitant) will be sufficient to provide a basis for the plaintiff to commence proceedings.

This allows the plaintiff to commence proceedings against the foreign defendant anywhere within the common market area - the only limit being any domestic private international law within the particular state or jurisdiction which controls what cases the court addressed hears. To the extent these laws facilitate forum bias or incentivise forum shopping, the foreign defendant is put at a severe disadvantage in arguing that there case should be heard in another forum. ${ }^{12}$ Assuming the court then decides to hear the case and enters judgment in the plaintiff's favour, the reciprocal judgment regime will then mean that this judgment becomes automatically enforceable throughout the entire market area. ${ }^{13}$ The plaintiff is able to access the assets of the foreign defendant anywhere within that common market area, under the applicable enforcement regime.

\footnotetext{
${ }^{7}$ Mortensen, above n 2, at 90-91.

${ }^{8}$ See K Nadelmann “The Outer World and the Common Market Experts' Draft Convention on the Recognition of Judgments" (1968) 5 CML Rev 409.

${ }^{9}$ Mortensen, above $\mathrm{n} 2$, at 90-91.

${ }^{10}$ Ibid at 90 .

11 Ibid.

12 See the Trans-Tasman Proceedings Act 2010 (Cth), ss 17-19.

${ }^{13}$ Subject to a few exceptions e.g. see the Trans-Tasman Proceedings Act 2010 (NZ), s 61, Trans-Tasman

Proceedings Act (Cth), s 72 as an example.
} 


\section{Overview}

The key argument which will be made is that the outer world problem is present under the TTPA scheme, and arises in Australia because of the high chance of retention of cases where a foreign defendant is a party when compared to New Zealand. ${ }^{14}$ This can be seen with reference to established criteria which makes up the problem, as sourced from various academic discussions on the issue. All these elements are satisfied, specifically that the TTPA scheme regulates forum issues for common market residents, and fails to do so for noncommon market residents, which results in Australia's private international law being applicable when resolving the issue of the most appropriate forum to hear the dispute in cases where proceedings have been filed in Australia against a foreign defendant. It will be argued that the current state of its law in this respect is patently biased towards retaining such proceedings (including in cases involving commercial contractual disputes). ${ }^{15}$ Finally, where the Australian court resolves to retain the case, and, in the event it gives judgment in favour of the plaintiff, this is readily enforceable in New Zealand under the Trans-Tasman Proceedings Act 2010 (NZ), with little scope for challenge. Ultimately it will be argued this result in significant unfairness to the defendant, and any advantages for the plaintiff can be argued to less than persuasive. This unfairness justifies reform, albeit what form that it should take is a difficult issue with some tentative solutions being offered. Ultimately a more thorough review of the TTPA scheme in light of the outer world problem is recommended, something which did not occur as part of the review process carried out by an intergovernment panel over the course of 2005-2008.

In many respects the TTPA and the Christchurch Agreement marks a positive move towards greater economic integration and trust between two nations with a long-standing history of friendship and close political ties. ${ }^{16}$ The outcome will arguably be the growth of trade and, in the round, a positive development for both countries. This must inevitably be kept in mind when highlighting any issues with the TTPA. However the present issue of the outer world problem and its position under the TTPA is one, on face value, easily remedied. The misalignment of New Zealand and Australian private international law rules highlights our

\footnotetext{
${ }^{14}$ See footnote 43 .

15 Excluding cases involving non-exclusive choice of court agreements however.

${ }^{16}$ J L R Davis “Closer Economic Relations - A Trans-Tasman Confederation?” (2010) 16 Canta LR 47 at 47.
} 
partner' existing "forum-biased" approach to resolving international disputes as the cause of the outer world problem. ${ }^{17}$

This arises from the combined effect of the dual incorporating pieces of legislation. On the one hand, the Trans-Tasman Proceedings Act 2010 (Cth) proportionate jurisdictions (contained within s 19 of the Act), do not apply where a defendant is arguing that a forum outside the common market (i.e. New Zealand and Australia) is the more appropriate one. ${ }^{18}$ The default applicable regime is therefore the domestic private international law of Australia, in cases where the plaintiff has commenced proceedings in that forum against a foreign defendant. ${ }^{19}$ The current state of Australia's private international law means that it is highly likely that the court addressed will retain proceedings commenced properly in that forum, even where there is a strong case that another forum is the more appropriate one. ${ }^{20}$ There is the potential that in some cases the Australian court will, having decided to retain the proceedings, then give judgment in favour of the plaintiff. These cases are the focus of this paper.

The Trans-Tasman Proceedings Act 2010 (NZ) does apply when it comes to the question of enforcing this resulting judgment, even though it fails to regulate the issue of forum. ${ }^{21} \mathrm{In}$ general the judgment (obtained under the domestic private international law of Australia) will become automatically enforceable throughout the entire common market. ${ }^{22}$ This meets all the criteria of the outer world problem, as noted by various academics, such as Mortensen. ${ }^{23}$

D Outer World Problem and Commercial Contract Disputes

A key point of discussion for the purposes of this paper is the impact that commercial contract disputes will have on the outer world problem. In some cases, such disputes will be

\footnotetext{
${ }^{17}$ See Mortensen above n 2, at 90-91, Oceanic Sun Line Special Shipping Co Inc v Fay (1988) 165 CLR 197 (HCA) at 238, 240, 247-248, 266 per Brennan, Deane and Gauldron JJ, rejecting the English House of Lords approach to forum conveniens in Spiliada Maritime Corporation v Cansulex Ltd [1987] 1 AC 460 (HL). In the later Australian High Court decision in Voth v Manildra Flour Mills Pty Ltd (1990) 171 CLR 538 (HCA), the Oceanic position was expressly approved at 572.

${ }^{18}$ See footnotes $50-56$.

${ }^{19}$ See footnotes 57-61.

${ }^{20}$ See footnotes $62-134$.

${ }^{21}$ See footnote 146.

${ }^{22}$ See footnotes 147-161.

${ }^{23}$ See footnote 40 .
} 
regulated by a choice of court agreement in the contract. ${ }^{24}$ The parties will have pre-arranged the forum in which there dispute is to be heard at the time of contract formation. Therefore, the issue of which forum (Australia or the foreign defendant's preferred choice of forum) is the more appropriate one will have already been resolved by the parties. The issue of bias potentially does not arise, because the parties will have pre-regulated the issue of forum. A party may seek to challenge such a clause, and this is where forum bias arises under Australian private international law.

The defendant can hardly claim they have been treated unfairly when they are required to defend proceedings in a pre-arranged forum. Arguably then there is no need (at least in the context of commercial contractual disputes) for reform. However this ignores the reality that in Australia (where the outer world issue arises), courts retain ultimate discretion as to whether to uphold the parties choice of court agreement where one party has challenged. ${ }^{25}$ Such a position also ignores the types of clauses which could be present in a commercial contract, with respect to the issue of forum, and the impact this will have on the applicable legal test when the court must decide where the dispute is heard. Under Australia's existing case law, a high degree of forum retention in breach of such agreements further highlights the need for reform, or at least discussion of the outer world problem. ${ }^{26}$ In cases where there is no choice of court clause in the agreement, the contractual dispute will be regulated under conventional forum non conveniens principles. ${ }^{27}$ The importance of discretionary tests such the doctrine of forum non conveniens, as the gateway through which proceedings are allocated remains present for commercial contract disputes.

E The Outer World: a problem at all?

\footnotetext{
${ }^{24}$ For pre-TTPA New Zealand authority on the relevancy of choice of court clauses in resolving the issue of the appropriate forum see Bramwell v The Pacific Lumber Co Ltd (1986) 1 PRNZ 307 (HC), Air Nauru v Niue Air Lines Ltd [1993] 2 NZLR 632 (HC), Society of Lloyd's \& Oxford Members' Agency Ltd v Hyslop [1993] 3 NZLR 135 (HC). The position for TTPA cases is now governed by the Trans-Tasman Proceedings Act 2010 (NZ), s 25, Trans-Tasman Proceedings Act 2010 (Cth), s 20.

${ }^{25}$ As a general statement this would appear to be incorrect pre-TTPA - these three cases all establish that New Zealand Court's retain a residual jurisdiction even where there is a choice of forum clause which submits to the exclusive jurisdiction of a particular forum (see cases at footnote 9). See David Goddard QC and Campbell McLachlan QC "Private International Law - litigating in the trans-Tasman context and beyond" (paper presented to NZLS CLE conference, August 2012) at 51. In terms of Australia the position is the same, see Akai Pty Ltd v People's Insurance Co Ltd 188 CLR 418 (HCA) at 428, Kingston Estate Wines Pty Ltd v Vetreria Etrusca Srl [2007] SADC 102 at [24]-[25].

26 Mortenson, above n 2, at 81.

${ }^{27}$ See as a New Zealand example Longbeach Holdings Ltd v Bhanabhai \& Company Ltd CA Wellington CA11/93 6 Dec 1993, for Australia see Contractors Ltd v MTE Control Gear Ltd [1964] SASR 47 (SC) at 50.
} 
A point of contention is to what extent the outer world problem is a "problem" at all. Selfevidently the key issue is fairness towards the parties, and what (if any) unfairness is caused to the defendant by the problem balanced against the advantages in terms of enforcement received by the plaintiff. There are a number of potential arguments. These include the unfairness the TTPA causes to defendants (specifically those who are foreign) by failing to regulate the issue of the most appropriate forum, ${ }^{28}$ which is further compounded by the manner in which the Australian judgment then becomes automatically enforceable throughout the common market. From the defendant's perspective, the real unfairness of the outer world problem is manifested in the ability of the plaintiff to access their assets (via the reciprocal enforcement regime) in New Zealand. Other issues may also include the purpose of the Christchurch agreement and the TTPA regime, which was (arguably) to facilitate the enforcement of judgments against common market residents and business owners rather than judgments against foreign defendants. ${ }^{29}$

Counter arguments might include that fairness issues raised by the relationship between the TTPA and Australia's private international law merely systemic of arguments around whether the role of private international law is to prevent forum shopping. ${ }^{30}$ The outer world problem is a prime example of forum shopping, as the plaintiff will seek to have their claim against the defendant resolved in that state because of advantages from the substantive and procedural law of that forum, as well as other factors. ${ }^{31}$ Independent of appropriate forum issues, there is the further question of the impact that international commercial contracts will have on the question of fairness to the defendant, as the parties can elect forum which will resolve the dispute. This also needs to be addressed.

\section{F Reform}

\footnotetext{
${ }^{28}$ See footnote $163-174$.

${ }^{29}$ Trans-Tasman Proceedings Act 2010 (NZ), s 3(1)(b), Trans-Tasman Proceedings Act 2010 (Cth), s 3(b), Trans-Tasman Working Group, Trans-Tasman Court Proceedings and Regulatory Enforcement: A Report by the Trans-Tasman Working Group (Ministry of Justice, December 2006), at 9-12.

${ }^{30}$ See Brian R Opeskin “The Price of Forum Shopping: A Reply to Professor Juenger” (1994) 16 Syd LR 14 at 21-22, compare F K Juenger "What's Wrong With Forum Shopping” (1994) 16 Syd LR 1 at 10-11.

31 Andrew S Bell Forum Shopping and Venue in Transnational Litigation (Oxford University Press, Oxford, 2003 ) at 25.
} 
If it is accepted that reform is justified because of the unfair treatment of the defendant under the outer world problem, then how would this be achieved $?^{32}$ Additionally international commercial contractual arrangements raise different issues, and therefore approaches to reform as opposed to cases resolved under conventional forum non conveniens principles. ${ }^{33}$ Legislative reform of the TTPA (Cth) could be one solution however this raises a number of issues. ${ }^{34}$ Another option could be court led reform by aligning the current private international of New Zealand and Australia. The current position in New Zealand in terms of conventional forum non conveniens applications (i.e. where there is no choice of court clause) is governed by the House of Lords decision of Spiliada Maritime Corp v Cansulex $L t d .{ }^{35}$ The alignment of New Zealand and Australian private international law could provide one solution to the outer world problem, without raising the need to deal with the enforcement issues under the TTPA. ${ }^{36}$ However this would require Australia to overrule its current approach to forum non conveniens applications and adopt the test in Spiliada. ${ }^{37}$ Forum non conveniens (latin: forum not convenient) is a well-known discretionary principle utilised by most common law systems as a means of controlling the kinds of disputes a forum will hear (based on how closely connected they are with that forum). Courts may rule themselves or another forum "forum non conveniens" to hear the dispute by granting a stay of the proceedings, or refusing one. This discretion sits above rules based jurisdictional rules which allow proceedings to be commenced and served against defendants located outside of

\footnotetext{
${ }^{32}$ Additionally it is argued that under established principles of international comity, Australian and New Zealand governments should have given greater consideration as to how the outer world problem under the TTPA might have been perceived by other countries, see footnote 162 .

${ }^{33}$ See footnote $202-204$.

${ }^{34}$ The intent of the TTPA was clearly to provide for a regime which would only apply in terms of disputes where the parties were from Australia or New Zealand (see Trans-Tasman Working Group, Trans-Tasman Court Proceedings and Regulatory Enforcement: A Report by the Trans-Tasman Working Group (Attorney General's Department (Australia) Ministry of Justice (New Zealand), December 2006) at 10, Trans-Tasman Working Group, Trans-Tasman Court Proceedings and Regulatory Enforcement: A Public Discussion Paper by the Trans-Tasman Working Group (Attorney General's Department (Australia) Ministry of Justice (New Zealand), August 2005), Trans-Tasman Proceedings Bill 105-2 (select-committee report), (23 March 2010) 661 NZPD 9702, (18 March 2010) CAPD 2215 (Cth)), therefore amending incorporating legislation to apply to disputes where one of the parties is located outside of the common market contrary, to the intent of the original legislation, the Christchurch agreement, and the underlying purpose of the legislation (which was to facilitate trade between the Australia and New Zealand, not other countries, see New Zealand Treasury, Regulatory Impact Statement - Implementation of Recommendations of Trans-Tasman Working Group on Court Proceedings and Regulatory Enforcement (New Zealand Treasury, November 2009) at 1).

${ }^{35}$ Spiliada Maritime Corp v Cansulex Ltd, above n 17, Bomac Laboratories Ltd v Life Medicals (MSDN BHD) [2012] NZHC 363 at [8].

${ }^{36}$ This option would mean that at least concerns of fairness to the defendant in terms of enforcement of the Australian judgment in New Zealand, under the TTPA, would be mitigated, because the issue of forum in Australia would have (arguably) have been resolved in a more partisan manner. However see footnotes 62-134, similar issues in terms of bias under the Spiliada test could arise as under Australia's current private international law.

${ }^{37}$ See Voth v Manildra Flour Mills Pty Ltd, above n 17.
} 
the jurisdiction, and depending on the type of case, with or without the leave of the court. Australia and New Zealand both have these features present in their system of private international law - however where they differ is in terms of the willingness to grant stays. The Australian approach can be highlighted by a high degree of bias towards refusing stays, even where the case has a close connection with another forum. In contrast, the New Zealand approach under Spiliada, should theoretically result in a greater chance of a stay being granted in the same scenario, although some New Zealand cases would seem to indicate the opposite conclusion. $^{38}$

The House of Lords decision in Spiliada has also been subject to vehement academic criticism and raises its own issues as possible alternative to reform. The best approach is likely to be legislative reform, removing judgments against foreign defendants (obtained under the private international law of Australia) from the expedited process for enforcement in New Zealand under the TTPA as this addresses the issue of fairness to the defendant but avoids other issues which arise from alternative methods of reform.$^{39}$

\section{Outer World Problem under the TTPA}

\section{A Introduction}

That the outer world problem is present under the TTPA can be seen by analysing the legislative regime which incorporates the Christchurch Agreement. Mortensen (and other academics) conception of the outer world problem can be broken down into four key elements: ${ }^{40}$

1. The common market regime regulates forum issues where parties are closely connected with common market, and disputing between particular state(s) within the common market as to which is the appropriate forum; ${ }^{41}$

\footnotetext{
${ }^{38}$ See footnote 42.

39 See Anthony Gray "Forum Non Conveniens in Australia: A Comparative Analysis" (2009) 38 CLWR 207, at 214-219, 228-230.

${ }^{40}$ Mortensen, above n 2, at 90-91, K Nadelmann "Clouds Over International Efforts to Unify Rules of Conflicts of Laws" (1977) 41 LCP 54 at 58-62, M Pryles and FA Trindade "The Common Market (EEC) Convention on Jurisdiction and Enforcement of Judgments in Civil and Commercial Matters - Possible Impact Upon Australian Citizens" (1974) 48 ALJ 185 at 193-194.

${ }^{41}$ The purpose of breaking down the outer world problem into elements is to distil key features for the purpose of identifying to what extent the outer world problem arises under the TTPA. This first element raises a number of definitional issues however, as the extent to which the legislation applies (or does not apply) to legal disputes
} 
2. The common market regime fails to regulate forum issues in the case of foreign defendants who are not closely connected with the common market;

3. The domestic private international law of the common market state addressed, compared to the common market arrangements, is biased towards retaining proceedings in that state where they have been commenced (e.g. despite the fact that the link between the dispute and that forum may be tenuous); and

4. The common market provides for a streamlined reciprocal enforcement regime of civil judgments (whether or not the liable parties dispute was regulated by the common market forum allocation test)).

\section{B TTPA: Outer World Problem}

\section{Common Market Regulates Forum Issues}

with a connection to the common market depends on the frame of reference with reference to the party's connection to the market. For example, Mortensen's articulation of the of the first element of the outer world problem focuses on the fact that the TTPA regime will only apply to parties where they are served within the common market (see Mortensen, above n 2, at 90-91), which is correct - see footnotes 52 and 54). But this would appear to be over simplistic as clearly not all parties who might have been served within the common market (i.e. physically present) will be permanent or long-term residents there, or have a business presence there (see Mortensen, above n 2, at 90-91). If one of the key issues in terms of the outer world problem is that it results in discrimination of foreign defendants in how they are treated vis common market residents when resolving the issue of forum, then surely a definition must clearly articulate to what extent the legislation does or does not apply to parties that do or do not have a close connection with the common market. However alternative definitions to whether the legislation just applies to those served within the common market also raise difficulties - for example defining the outer world problem with reference to nebulous concepts such as whether the parties have a "connection" with the common market provides insufficient guidance with reference to the issue of whether the outer world problem is present under the common market regime. The better approach would appear to be focus on established private international law principles when considering whether a party has a close connection with a particular forum, namely whether they are domiciled in that state. Again such a concept is equally nebulous and depends closely on the facts of the particular dispute, making it difficult to generalise (see Ellwood v Federal Commissioner of Taxation [2012] AATA 869, at [18]-[26]).

For present purposes a definition which delineates between parties which are merely present in the common market and those which have a closer connection in the sense they may have resided there for a lengthy period of time or carry out business there / have a business presence within the common market provides a useful starting point. Again this definition is less than convincing but at least addresses the issue raised by Mortensen's definition, namely focusing on whether the party is physically present in the common market is misleading as it does not fully determine whether the party has a meaningful (or lack of meaningful) connection with the common market, specifically Australia. 
(a) Legislative scheme

Taking the first element of the outer world problem, and the Australian legislation (where the outer world problem begins), ${ }^{42}$ proceedings are commenced by way of service of an initiating document ${ }^{43}$ on the other party. ${ }^{44}$ The originating process (as long as it is served in accordance with the TTPA), has the same effect and gives rise to the same proceedings as if they had been served in Australia. ${ }^{45}$ The defendant then has two options. They may

\footnotetext{
${ }^{42}$ For the purpose of this paper the author has focused on how the outer problem arises where proceedings are commenced in Australia against a foreign defendant, and the resulting judgment is sought to be enforced in New Zealand as opposed to the reverse position (i.e. proceedings commenced in New Zealand against a foreign defendant, and then the judgment is sought to be enforced in Australia). This is where the "outer world problem" arises under the TTPA regime, because of the domestic private international law of Australia is biased towards retaining proceedings commenced against a party to a dispute, despite there being a strong argument that another forum is the appropriate one based on the particular facts of the case (see footnotes 62-134). Ease of enforcement of any resulting judgment in New Zealand (although the practical reason the foreign defendant cares about the outer world problem), alone arguably causes no unfairness to the foreign defendant (see footnote 164). Logically therefore the focus in the balance of the paper will be on the Australian legislation (i.e. the Trans-Tasman Proceedings Act 2010 (Cth) in terms of forum allocation at the commencement stage of the proceedings, and then the New Zealand legislation (i.e. the Trans-Tasman Proceedings Act 2010 (NZ) when it comes to the issue of enforcing the Australian judgment in New Zealand.
}

Arguably the problem does not arise in the reverse scenario, because of the applicable domestic private international law (which applies as the default regime regulating the issue of forum allocation in the absence of another regime applying e.g. the TTPA), is not biased towards retaining proceedings commenced in New Zealand. See Mortensen, above n 2, at 90-91. Mortensen's conception of the outer world problem focuses on the fact that the leading forum non conveniens case in New Zealand (the English House of Lords decision in Spiliada) is the touchstone for reform, on the basis that the test balances the parties interests vis the issue of forum more fairly than current Australian arrangements (i.e. his suggestion for reform would be that the Australian legislatures or High Court mandate the application of Spiliada as opposed to the current leading test test in Voth). His solution is predicated on the basis that current problem under the TTPA can be remedied by aligning the private international law of both common market countries so that all disputes are subject to a more balanced test. However recent New Zealand case law on forum non conveniens applications indicates that New Zealand courts may well be much closer to Australian courts in terms of their approach to allocating forum than the different tests would indicate. See for example the recent New Zealand High Court decision in Bomac Laboratories Ltd $v$ Life Medicals, above n 35, at [8]-[30], where a stay was refused on the basis that Malaysia was not the more appropriate forum to resolve the dispute, in circumstances where the connecting factors (e.g. witness location, comparative expense of trial in New Zealand versus Malaysia) pointed towards the dispute being more closely connected with that forum rather than New Zealand. Ultimately an application for a stay was refused by the High Court on review (at [33]). The illustrates the point that despite New Zealand private international law being arguably more "balanced" because of the legal test applied when hearing applications for a stay (at least on face value), because of a large amount of discretion under such tests there is scope for bias to arise through the manner in which individual judges resolve particular cases e.g. in the way they interpret specific factors or balance them. This point was expressly made by the High Court in Bomac (albeit in the context of commenting on the High Court's role when reviewing the decision of an Associate Judge of the High Court, at [20]). A fuller analysis of whether the outer world problem arises in both New Zealand as well is beyond the scope of this paper, although the problems identified by the Bomac approach will later be discussed when it comes to the issue of reform of the TTPA.

${ }^{43}$ Trans-Tasman Proceedings Act 2010 (Cth), s 4, definition of "initiating document".

${ }^{44}$ Section 9.

${ }^{45}$ Section 10. 
either file an appearance ${ }^{46}$ or apply for a stay of the Australian proceedings on the grounds that a New Zealand Court is the more appropriate forum, within 30 days of being served with the originating process, under s $17 .{ }^{47}$ The TTPA provides for a list of non-exhaustive factors in s 19 which must be taken into account by the Australian court when determining whether to grant a stay under s $17 .{ }^{48}$ Section 19 is the pivotal section in terms of the issue of resolving the issue of forum. Section 19 explicitly states that it only applies to an application for a stay under s 17. Section 17 of the Australian legislation provides that:

(1) A defendant in a civil proceeding in an Australian court may apply to the court for an order staying the proceeding on the grounds that a New Zealand court is the more appropriate court to determine the matters in issue.

(2) The application must be made within:

(a) 30 working days of the Australian court after the day on which the defendant was served with the initiating document for the proceeding; or

... (emphasis added)

The TTPA does not explicitly state that it applies to disputes between parties resident or closely connected with the respective common markets state. ${ }^{49}$ However the legislation will apply where the parties are physically present within the common market and are arguing between whether New Zealand or Australia is the more appropriate forum. The former point will generally mean that the defendant will need to have been physically present in the common market for the test in section 19 to apply - the latter that they have a close connection with the forum as per element one of the definition of outer world problem, outlined above.

This first point is made clear from the scheme of service under the legislation. Service of an initiating document must be made on parties located within the common market in accordance with the relevant rules of Court in the place in which proceedings were issued. ${ }^{50}$ Section 9 envisages (under the Australian legislation / court rules) that the defendant will

\footnotetext{
46 Section 13.

47 Section 17.

${ }^{48}$ Section 19.

${ }^{49}$ See the discussion at footnote 58 - for example the legislation is not expressly limited to parties which are domiciled within Australia or New Zealand - see Trans-Tasman Proceedings Act 2010 (Cth), Trans-Tasman Proceedings Act 2010 (NZ).

50 Trans-Tasman Proceedings Act 2010 (Cth), s 9(2)(a).
} 
have been served in New Zealand, based on the express wording of the section. ${ }^{51}$ In most Australian courts, service of the originating process will generally require personal service on the defendant where they are a natural person. ${ }^{52}$ In terms of other defendants (e.g. corporations, partnerships), the court rules in the various Australian states and territories provide for different means of service. Generally service can occur via serving the originating process on the president or some other head officer, or the director of the corporation, in accordance with the provisions of the federal Corporations Act 2001 (Cth). ${ }^{53}$ Under that Act a corporation (i.e. companies and incorporated societies) may also be served with the originating process either via post or personal service at the registered office of the corporation. ${ }^{54}$ As service of the initiating document under s 9 is a pre-requisite before the defendant can apply for a stay under ss $17 / 19,,^{55}$ the service scheme indicates that the

\footnotetext{
${ }^{51}$ Ibid.

${ }^{52}$ Section 9(1)-(2) make it clear that to effect service of the originating process on the defendant present within New Zealand, this must be done in accordance with the relevant rules of court in the "place of issue" (which means, in relation to an initiating document or subpoena issued by an Australian court or tribunal, the State or Territory in which the court or tribunal issued the document), section 4 definition of "place of issue". An initiating document is defined as a document by which a civil proceeding is commenced in an Australian court or tribunal; or by reference to which a person becomes a party to a civil proceeding in an Australian court or tribunal. Generally all Australian states and territories (in terms of the relevant civil court rules) require personal service on a natural defendant to effect the originating process (i.e. personal service is effected by personally delivering and leaving a copy of the document with the defendant in the event they refuse to accept service), see Bernard Cairns, Australian Civil Procedure (10th ed, Thomas Reuters, Sydney, 2014) at 4.20. Originating process is used to refer to the document which must be filed in the relevant court and served on the defendant to commence the proceedings. Because service of the originating process must be carried out personally on the defendant within New Zealand (in accordance with Australian civil court rules) with respect to natural persons and therefore they will have to be at least physically present within the jurisdiction for the legislation (particularly the test in s 19) to apply to their civil dispute.

${ }^{53}$ Bernard Cairns, above n 55, at [4.30]. See [4.50] for partnerships (generally personal service on the partner or a person who manages the partnerships business, at their principle place of business and containing a notice which indicates what capacity the person is being served in i.e. manager or partner).

${ }^{54}$ Similar to natural defendants, corporations will generally need to be physically located within New Zealand to be served under s 9 . To be served at its office, the company will need to have been incorporated under the laws of New Zealand to have a registered office or be carrying on business within New Zealand (see Companies Act 1993 (NZ), s 334(1)). Personal service on company officers or other head officers however creates a potential argument that the TTPA could be utilised to serve proceedings on companies with no physical presence within the common market (other than the officer being fortuitously present within New Zealand), and therefore the ability to commence proceedings under the TTPA where the defendant corporation has little connection with the common market. This will be discussed further below (see footnote 59 ).

${ }^{55}$ Section 17(2(a) corroborates the point that, despite the ambiguity in s 17 as to whether the scheme could apply to non-common market defendants, the TTPA scheme was intended to only regulate disputes where the parties were located within the common market. This can be seen by analysing the surrounding context of s 17 . An application for a stay under s 17 must be made within 30 working days after the day on which the defendant was served with an initiating document. An initiating document is one which commences the proceedings in an Australian court, in the prescribed form. Section 9 provides that an initiating document may be served in New Zealand without leave of the Australian Court, which issues the originating process. Clearly the drafters of the legislation envisaged that an application for a stay under s 17 would be made in cases where proceedings had been served under s 9 , because of the express mention of service of "an initiating document" in section 17(2)(a) with reference to the timeframe the defendant has to apply for a stay under s 17 . This would confirm that an application for a stay would only be made in cases where the defendant had been physically served with proceeding in New Zealand, meaning it would be likely they were a common market resident.
} 
defendant (no matter what type of entity) will have to have been at least physically present within New Zealand for the TTPA to apply to their dispute.

In terms of the second point, for the defendant to avail themselves of the relevant test under s 19, s 17 also stipulates that they must be arguing that, as opposed to Australia (where the proceedings will have been commenced under s 9), New Zealand is the more appropriate forum. Logically it will generally be a defendant located within New Zealand who seeks to have the proceedings heard there. ${ }^{56}$ Although the service aspect of the legislation focuses on physical presence, the fact that the defendant must be arguing that New Zealand is the more appropriate forum (for the test in s 19 to apply) will generally mean that the legislation applies to parties with a close connection to the common market e.g. they will be physically present in the market and will be seeking to have the forum resolved in New Zealand.

\section{Common market fails to regulate forum issues for foreign defendant}

On face value the legislation appears ambiguous in terms of whether the test in s 19 applies just in cases where the defendant and plaintiff have a strong connection with the common market, or whether it applies to non-market residents or businesses as well, who have little / no connection with the common market. This ambiguity arises from the focus on service under the legislation, and what forum the defendant is arguing is more appropriate, rather than other well-known private international law concepts such as residence or domicile. For example s 17(1) indicates that that the section 19 test only applies where the defendant (who will logically be arguing for a stay), ${ }^{57}$ is arguing that New Zealand is the more appropriate forum. Additionally there is no express limit placed on whether the legislation applies to disputes where the parties are domiciled, nationals, or otherwise have a presence within the common market. ${ }^{58}$ So feasibly a non-resident or foreign business, might attempt to argue

\footnotetext{
56 Goddard and McLachlan, above n 25, at 15.

${ }^{57}$ If the defendant does not wish to oppose the plaintiff's choice of forum (Australia) then the issue of the applicability of the Trans-Tasman Proceedings Act 2010 (Cth) and the outer world problem does not arise. In such circumstances the defendant can hardly be heard to complain of any unfairness that arises from failing to oppose the plaintiff's choice of forum.

${ }^{58}$ Common market regimes vary in terms of the manner in which they "apply" to legal disputes. For example the European Union "Brussels Model" cross-enforcement regime applies where the party is domiciled (for both individuals and companies, and other legal entities) within a state part of the European Union, with specialist jurisdictional rules developed to for particular disputes. The phrase "domiciled" is undefined in the regulations but, for example, has been defined in with reference to individuals by the incorporating United Kingdom legislation as residence in, and a substantial connection with, the United Kingdom (see Civil Jurisdiction and Judgments Act 1982 (UK), ss 41,42). A substantial connection is presumed after three months' residence but
} 
that because they will apply for a stay in favour of New Zealand being the more appropriate Court, section 17 applies to them. The better argument would appear to be that despite the ambiguities arising from service (e.g. the potential for residents and businesses to be served within the common market under Australian civil rules, despite the fact they are only temporarily present in the jurisdiction), the requirement that the defendant must be arguing that New Zealand is the more appropriate forum will generally make it highly unlikely that the legislation will apply to non-common market residents. ${ }^{59}$ Logically they will be arguing for a stay in favour of another forum, but the possibility of applying for a stay on these terms is impossible under s 17 / 19 the only alternative forum is New Zealand. ${ }^{60}$ Consequently element two of the outer world problem is clearly satisfied, as in all cases the test in s 19 will not apply unless the foreign defendant is (in most cases) physically present within New Zealand and is arguing New Zealand is the more appropriate forum when seeking a stay in accordance with s 17 . It is highly unlikely a fact scenario would arise. ${ }^{61}$ Therefore in cases

this can be rebutted. In terms of corporations or associations, the focus is on the location of the "seat of the corporation" (which is ascertained with reference to whether the company was formed under the law of a part of the United Kingdom and has its registered office or some other official address in the United Kingdom, or ). There are also special jurisdictional rules for certain types of proceedings. For example in the case of a contractual dispute, courts in the place where contractual obligations are performed have jurisdiction over contractual disputes. Again these rules apply even if the defendant is domiciled in another jurisdiction. Some of these rules give non-exclusive jurisdiction to a court and others confer exclusive jurisdiction. Whether a court can assume jurisdiction under a special rule involves deciding whether the proceeding is of a particular kind. Then any connecting factors specified in the rule must be applied. If, as is quite possible, courts in more than one State have jurisdiction, the model regulates priority between them on the basis that the court where proceedings first began has jurisdiction. See Regulation 44/2001 on jurisdiction and the recognition and enforcement of judgments in civil and commercial matters [2001] OJ L012. Such regimes provide a useful comparison in terms of how the TTPA regime could have been set-up to provide greater clarity around the issue of which disputes it applies to.

${ }^{59}$ Residents is used to refer to individuals - businesses (the focus of this paper) can of course include a sole trader and in this sense the way the legislation does or doesn't apply to individuals directly impacts on the outer world problem and whether the first element of the problem is present under the TTPA with respect to commercial contractual or B2B contractual disputes (to some extent). In terms of businesses (i.e. entities trading through a company or some other form of separate legal entity such as partnership or an incorporated society) the TTPA does not apply unless the business has a physical presence in New Zealand (in the form of a registered office), see footnotes 53-54. However there is potential for the business to be served in New Zealand despite the absence of any physical presence in the jurisdiction, under Australian civil rules relating to service. In terms of the definition of element two of the outer world problem, this would of course potentially mean the legislation could be argued to apply to foreign defendants with little / no connection to the common market, based on Australian civil court rules and the possibility for service under the TTPA to occur without any registered office or business presence in New Zealand (e.g. an officer of the company being fortuitously present in the jurisdiction). The better conclusion is that the application of the TTPA to a civil dispute where there is at least one party is located outside of the common market is highly unlikely, as it would still require the foreign business to then be arguing (in accordance with s 17) that New Zealand was the more appropriate forum, when they are much more likely to be arguing that another forum is the more appropriate one. From the foreign defendant's perspective many of the issues with Australia being the forum to hear the dispute (e.g. costs associated with defending foreign disputes, travel costs, costs of witness disbursements, potential procedural disadvantages) are likely to arise in New Zealand as well, and it would therefore appear nonsensical that they would prefer New Zealand as the more appropriate forum and argue this when seeking a stay.

${ }^{60}$ Trans-Tasman Proceedings Act 2010, ss 17, 19.

${ }^{61}$ See footnote 59. 
where the foreign defendant has little connection with the common market, the TTPA (specifically the test in s 19), will not apply, and the case will be governed by the private international law of Australia.

\section{Domestic Private International Law of Australia is Biased}

(a) Introduction

As noted by both Mortensen and Gray, Australia's private international law is characterised by a high degree of forum bias in the sense that Australian courts are much more willing to retain proceedings properly commenced by a plaintiff within the jurisdiction, even where there is a strong connection with another forum. ${ }^{62}$ The issue of whether proceedings have been properly commenced (i.e. based on the forums jurisdictional rules), and whether the forum addressed should retain them (forum non conveniens) can be distinguished. ${ }^{63}$ Case law in this area further bifurcates the applicable principles for contractual disputes, as to whether the proceedings are governed by the doctrine of forum non conveniens (i.e. contractual disputes where there is no choice of court agreement or the choice of court agreement is nonexclusive in the relevant contract) or an exclusive choice of court agreement (i.e. contractual disputes where there is a choice of court agreement in the relevant contract, and this is determined to have the legal consequence that the parties' submit to the exclusive jurisdiction of a particular court within a particular forum). ${ }^{64}$

\footnotetext{
${ }^{62}$ Mortensen, above n 2, at 80-81, 85, Gray. above n 39, at 229-230.

${ }^{63}$ In the sense that the former is concerned with jurisdiction, the later with whether the forum addressed is the appropriate forum to hear the dispute (based on various factors relevant under the relevant legal test e.g. see Spiliada Maritime Corporation v Cansulex Ltd, above n 17, at 474, 854). The distinction is based on the development of common law systems in terms of the extraordinary jurisdiction (or jurisdiction relating to the ability of courts to exercise coercive power over foreign defendants located outside of that courts state). For present purposes it is sufficient to note that under a common law system a plaintiff can have commenced proceedings properly but still ultimately have the proceedings stayed in that forum on the basis that a court in another forum is the more appropriate one, based on discretionary tests (e.g. forum non conveniens) applied by courts to regulate the disputes it hears, see Gray, above n 39, at 10-11, Michael Karayanni "The Myth and Reality of a Controversy: "Public Factors" and the Forum Non Conveniens Doctrine" (2003) Wisconsin Int'l LJ 327 , at 342-343. Consequently in common law systems such tests play an important role when ascertaining whether the private international law of that forum is biased when retaining proceedings, as a court having jurisdiction to hear the dispute is not the definitive touchstone for whether the court ultimately hears this dispute. In a wider sense then, jurisdiction as a meaningful concept not only includes rules which stipulate the types of cases that a court can hear but also discretionary tests such as the principle of forum non conveniens, as the former is not the definitive test for whether the case is ultimately heard by the court.

${ }^{64}$ Mortensen, above n 2, at 85 .
} 
This bifurcation of principles is important to identify at the outset, as this clearly impacts on the extent to which it is possible to argue that Australia's private international law is "biased", with respect to international commercial contracts. For example, it is difficult to argue that in civil proceedings for a claim arising from a commercial contract, the private international law of Australia is "biased", ${ }^{65}$ if say, the parties elected (in a choice of court agreement), that any dispute under their agreement was to be resolved in Australia. ${ }^{66}$ The issue of whether Australia's private international law is biased is more complex than merely assessing one particular fact scenario. Further issues arise as to the efficacy of this argument, and these issues will be discussed with reference to the particular kinds of fact scenarios which might arise in the context of a commercial contractual disputes. Ultimately Australian private international law displays a strong level of bias towards retaining proceedings despite the potential for other factors to impact on the applicable test the court will apply when allocating forum. ${ }^{67}$

(b) Forum Non Conveniens

i. Introduction

In the first scenario the international commercial contract will have no choice of court agreement. A choice of court agreement is a commonly used clause in commercial contracts between parties which are located in different states, in order to predetermine the issue of the court which will resolve their dispute. ${ }^{68}$ The absence of such a clause in the agreement impacts on the applicable legal test an Australian court when resolving the issue of the most appropriate forum to hear any dispute arising under the agreement. For conveniences sake these will be referred to as forum non conveniens cases.

\section{ii. $\quad$ Spiliada}

\footnotetext{
${ }^{65}$ And therefore responsible for proceedings being retained within one jurisdiction.

66 The logical argument is that the private international law of Australia can hardly be described as "biased" when it is merely giving effect to the ability of the parties to regulate their own affairs or private ordering.

${ }^{67}$ Mortensen, above n 2, a 72.

${ }^{68}$ Garnett defines such a clause as "... a provision in a contract whereby the parties agree to submit any disputes between them to a designated court." See R Garnett, "Stay of Proceedings in Australia: A “Clearly Inappropriate" Test (1999) 23 MULR 30, at 62.
} 
In terms of forum non conveniens cases, the leading Australian High Court cases have diligently avoided adopting the test promulgated by the House of Lords in Spiliada for international cases. ${ }^{69}$ The approach in Spiliada provides a useful comparator in terms of analysing the extent to which Australia's private international law is biased. As Gray notes, this is because the semantics of the tests and the role the court has in comparing the competing choices of forum differ under Voth $v$ Manildra Flour Mills Pty Ltd (the leading case under Australian private international law with respect to forum non conveniens cases) and Spiliada,. These differences highlight the bias under the Australia's private international law. ${ }^{70}$

The Spiliada forum non conveniens test can be characterised by the degree of proportionality it offers to both parties when resolving the issue of the most appropriate forum. ${ }^{71}$ Under the test, a court has discretion to stay proceedings where there is some other available forum, having competent jurisdiction, which is the more appropriate forum for the trial of the action, namely one where the case me tried more suitably for the interests of all parties and the ends of justice. $^{72}$

The test is broken down into two steps, ${ }^{73}$ with the initial onus being on the defendant, ${ }^{74}$ to convince the court addressed that there is some other available forum of competent jurisdiction which is more closely connected to the parties' dispute than that forum. In other words, it must be shown to the court addressed that a court of the alternative forum would assume jurisdiction over the case. In this respect, various factors are examined, with no single

\footnotetext{
${ }^{69}$ Gray, above n 39, at 214-219, Oceanic Sun Line Special Shipping Company Inc v Fay, above n 17, Regie National des Usines Renault SA v Zhang (2010) 210 CLR 575 (HCA), Dow Jones \& Company Inc v Gutnick (2002) 210 CLR 575, Puttick v Teon Limited (2008) 238 CLR 265 at 267-7, 280.

${ }^{70}$ Gray, above n 39, at 227.

${ }^{71}$ Mortensen, above n 2, at 73-74.

72 Spiliada Martime Corporation v Cansulex Ltd, above n 17, at 476.

${ }^{73}$ See L Collins Dicey Morris \& Collins on the Conflict of Laws (15th ed, Sweet \& Maxwell, London, 2012) at[12-029] - [12-046], A Briggs and P Rees, Civil Jurisdiction and Judgments (5th ed, Informa Law, 2009), at [4.13].

${ }^{74}$ In some jurisdictions this test has been amended so that it the onus remains on the plaintiff throughout both steps of the test e.g. see New Zealand, Wing Hung Printing Co Ltd v Saito Offshore Pty Ltd [2010] NZCA 502, [2011] 1 NZLR 754, High Court Rules 2014, r 6.29. Under Australian law and the test for a stay in Voth $v$ Manildra Flour Mills Pty Ltd, the onus remains on the plaintiff where prior leave to serve the proceedings on a defendant located outside of the jurisdiction is required. The plaintiff must show under Voth that i) the action is connected to the forum in one of the ways specified in the applicable rules of court (e.g. in a contract action, that the contract was made or breached within the forum, or was governed by the law of the forum), and ii) that the forum is not a clearly inappropriate one to hear the matter. In contrast, in cases where prior leave was not required to serve proceedings outside of the jurisdiction, or where jurisdiction has been invoked as of right under the common law rules (e.g. physical, albeit temporary, presence in the jurisdiction), the onus lies on the defendant to prove that the Australian court is a clearly inappropriate forum to hear the dispute. See R Garnett, above n 68, at 37, Voth v Manildra Flour Mills Pty Ltd, above n 17, at 538, 564-565.
} 
one necessarily being the decisive one. These factors typically include the degree to which the dispute and the events giving rise to their claim are connected with a particular forum and also the governing law of the parties' dispute. ${ }^{75}$ Additionally the alternative court must have competent jurisdiction to hear the claim, in the sense that court would recognise and hear the plaintiff's. If the court addressed determines that, after its inquiry under the first limb, that a foreign forum is more closely connected with the dispute than the court addressed, then the second stage becomes relevant. At this point, the claimant can seek to resist a stay on the basis that a substantial injustice for the plaintiff would result if the claim was heard in the more closely connected forum. ${ }^{76}$ To persuade the court that a stay should be refused at the second stage, the claimant can adduce evidence which points to examples of an injustice being caused at virtually any stage in the court process in the most closely connected forum. ${ }^{77}$ The sorts of factors that the court can consider at this stage include: ${ }^{78}$

“...risk that justice will not be obtained by a foreign litigant in particular kinds of suits, whether for ideological or political reasons, inexperience or inefficiency of judiciary, ... excessive delay in the conduct of the business of the courts or the unavailability of appropriate remedies... "79

iii. $\quad$ Voth

${ }^{75}$ Spiliada Martime Corporation v Cansulex Ltd, above n 17, at 476.

${ }^{76}$ Ibid at 478 .

${ }^{77}$ Ibid.

${ }^{78}$ The Abidin Daver [1984] 1 AC 398 (HL), at 411 per Lord Diplock. Although it will be apparent that the second limb of the test is focused on the plaintiff's interests in having their claim heard in the forum addressed, the plaintiff is required to provide cogent evidence that these factors / allegations are true (Spiliada Martime Corporation v Cansulex Ltd, above n 17, at 478), and the defendant is entitled to dispute or rebut any such evidence of injustice. Importantly, the two-stage test under Spiliada highlights an approach of balancing both parties' interests in the question of forum. Arzandeh notes that the focus of stage one of the test is a fact-finding analysis with the ultimate intention of preventing transnational commercial litigation in the forum addressed that has no connection to the forum (see Ardavan Arzandeh "Should the Spiliada Test be Revised" (2014) 10 J Priv Int L 89, at 89-91). The corollary of this point is that the first element of the Spiliada test is clearly aimed at identifying at a situation where a dispute is obviously not connected with the forum addressed, and this clearly rebuts any inference that can be drawn from the second element, that the test is somehow weighted more heavily towards the plaintiffs interests. In fact the paradigm feature under Spiliada is a balanced approach recognising both parties interests in resolving the issue of forum.

${ }^{79}$ Other factors may also include a more favourable limitation period (although most jurisdictions now provide that the applicable limitation period is governed by the lex causae of the dispute rather than the lex fori, rendering this factor somewhat redundant e.g. see Limitation Act 2010 (NZ), s 55), the availability of greater damages (e.g. the ability to recover interest on an outstanding debt), or the existence of assets within the forum for the satisfaction of any resulting judgment. See R Garnett, above $n$ 68, at 35 . 
In contrast, the leading Australian case, Voth v Manildra Flour Mills Pty Ltd, approaches the issue of forum by requiring the court to ask whether "it" 80 is a "clearly inappropriate forum" for dealing with the dispute before a stay is granted. ${ }^{81}$ This directs the court not to stay or dismiss the proceedings simply because there is a clearly more appropriate court with jurisdiction in the proceedings, located in another country. ${ }^{82}$ A significant feature of the test under Voth is the role of the court in comparing "Australia" (as the forum addressed) and the defendant's professed alternative forum. Under Voth the Court's role is not to balance the interests of justice with reference to the alternative forum. By this, it is meant that the Court is not concerned with the advantages or disadvantages (for each party) that arise from the potential that the case could be heard in another forum. ${ }^{83}$ These advantages or disadvantages include those listed above at the second stage of the Spiliada test, as well as many other conceivable factors which could vary significantly from case to case. ${ }^{84}$ Rather than such an expansive enquiry, the focus of the Australian Court in Voth is on advantages or disadvantages that will arise from the continuation of proceedings within Australia.

\section{iv. Trans-Tasman Proceedings Act 2010 (Cth), s 19}

It is also worthwhile providing some further analysis of s 19 of the Australian legislation, which provides a further illustration of how the position under Voth is biased towards retaining proceedings commenced in Australia and therefore whether element three of the

\footnotetext{
${ }^{80}$ In its capacity as the Australian Court hearing the application for a stay.

${ }^{81}$ Voth v Manildra Flour Mills Pty Ltd, above n 17, at 558.

${ }^{82}$ Ibid.

${ }^{83}$ Ibid at $560-561$.

${ }^{84}$ See Gray, above n 39, at 214-219. However confusingly (and perhaps absurdly in light of the Australian Court's rejection of the test in Spiliada) the factors listed as being relevant to element one and two of the test in the House of Lords decision are stated by the court as being be "equally valuable" in applying the "clearly inappropriate forum test" (see Voth, above n 17, at 564-565. Is not entirely clear what the difference is under the two tests (which obviously impacts on the extent Voth can be argued to be forum biased) - one tentative view is that because the role of the court in Voth is to focus on whether it, as the court addressed, is an inappropriate forum rather than undertaking a comparative exercise as to whether another court is "more appropriate", the inquiry of the Spiliada factors is only relevant to the extent the indicate the Australian court is a clearly inappropriate forum. Therefore, to the extent personal and juridical advantages exist in a foreign forum, these are irrelevant if they do not bear on the issue of whether the Australian court is a "clearly inappropriate forum" to hear the dispute. The better argument (as noted by Gray, Gray above n 39, at 226-228) is that the courts rejection of the balancing exercise in Spiliada (i.e. comparing the two forums in terms of which has the closer connection, as well as any potential juridical or personal advantages for the plaintiff in litigating in the chosen forum) is completely inconsistent with other statements in the judgment that these factors remain relevant under the clearly inappropriate forum test in Voth. This position has been expressly approved in later decisions of the Australian High Court (see Henry v Henry (1995) 185 CLR 571 at 592). In terms of the present issue of whether Australia's private international law is biased, there is still compelling evidence that this is the case (see below, footnotes 92-96).
} 
outer world problem is satisfied. This is also relevant to the discussion of how reform would be carried out to ameliorate the issue of the outer world problem. Section 19 provides the framework under which a court must consider any application for a stay under s 17 (including commercial contract cases where there is no exclusive choice of court clause), for proceedings served and commenced under the Trans-Tasman Proceedings Act 2010 (Cth). The court may only grant a stay in favour of another court (in the present scenario, a New Zealand court), where the court has jurisdiction to determine the matter at issue between the parties, and it determines that this court is the "more appropriate forum". Even where these first two elements are satisfied, the court still retains residual discretion to refuse a stay, although this discretion should only be exercised in exceptional circumstances. ${ }^{85}$ In considering whether the New Zealand court is the more appropriate court, the Australian court must have regard to the following factors: ${ }^{86}$

a. the places of residence of the parties or, if a party is not an individual, its principal place of business;

b. the places of residence of the witnesses likely to be called in the proceeding;

c. the place where the subject matter of the proceeding is situated;

d. any agreement between the parties about the court or place in which those matters should be determined or the proceeding should be commenced (other than an exclusive choice of court agreement to which subsection 20(1) applies) ${ }^{87}$

e. the law that it would be most appropriate to apply in the proceeding;

f. whether a related or similar proceeding has been commenced against the defendant or another person in a court in New Zealand;

g. the financial circumstances of the parties, so far as the Australian court is aware of them;

\footnotetext{
${ }^{85}$ See Re Featherston Resources Ltd [2014] NSWSC 1139, at [51]. This residual discretion is based on the syntax of s 19, which states that the Australian court "may" order a stay if the elements in s 19(1)(a)-(b) are satisfied. Note the comments in Re Featherston however stressing the exceptional nature of this residual discretion to order a stay, and noting it was unlikely such a case would ever fall within this category (ibid). Therefore any residual discretion would be unlikely (based on obiter statements such as those in $R e$ Featherston) to be used to refuse to order a stay even where the dispute had a satisfied the elements in $\mathrm{s}$ 19(1)(a)-(b).

86 Trans-Tasman Proceedings Act 2010 (Cth), s 19.

87 Trans-Tasman Proceedings Act 2010 (Cth), s 20. Under s 20, an Australian court must order a stay (or conversely must refuse an application for a stay under s 17), if the parties have entered into an exclusive choice of court agreement that designates a New Zealand court (or an Australian court) as the courts to determine the matters at issue. However even if such a choice of court agreement falls outside of the statutory definition in $\mathrm{s}$ 20(3), or is otherwise invalid under 20(2) (e.g. the clause is invalid under the laws of New Zealand), then s 19(2) mandates that it must still be taken into account by the court in considering whether to grant a stay under s 19 .
} 
h. any matter that is prescribed by the regulations; ${ }^{88}$ and

i. any other matter that the Australian court considers relevant.

The court is not permitted to take into account the fact that proceedings were commenced in Australia. ${ }^{89}$ In many respects, the test under s 19 is very similar to that provided for in Spiliada, albeit the basis of the test in s 19 is the cross-vesting scheme for trans-state disputes within Australia, rather than the common law test in Spiliada. ${ }^{90}$ This can be seen from the wording of s 19 (e.g. the reference to "more appropriate forum" as being the applicable test), the requirement the alternative forum have jurisdiction to hear the dispute, and the focus on a wide-ranging list of factors (many of which are similar or the same as those stated as being relevant to the question of a stay under Spiliada). ${ }^{91}$

\section{v. Comparison}

What then are the practical differences between the tests under Spiliada and s 19 of the Trans-Tasman Proceedings Act 2010, and conversely Voth, with reference to the issue of forum allocation? The first significant difference is the position the court addressed takes with respect to the issue of whether Australia is the appropriate forum to hear the dispute. Under Spiliada, the court is tasked with carrying out an analysis of whether there is another "more appropriate" forum in which the dispute could be more justly heard, having regard to the interests of both parties. A similar approach is clearly mandated under s 19 of the

\footnotetext{
${ }^{88}$ There are none currently.

${ }^{89}$ Section 19(2).

90 Trans-Tasman Working Group, Trans-Tasman Court Proceedings and Regulatory Enforcement: A Report by the Trans-Tasman Working Group (Ministry of Justice, December 2006) at 10, Service and Execution of Processes Act 1992 (Cth), s 20. The wording of section 20 of the Service and Execution of Processes Act 1992 largely mirrors section 19 , corroborating this point.

${ }^{91}$ As will be apparent from the factors under s 19, all of them would fall within the factors considered by the Court under the first element of the test for a stay in Spiliada, namely whether there is a forum more closely connected with the dispute than the one addressed. This would call into question to what extent the factors considered under the second element (i.e. whether there are any personal or juridical advantages to the plaintiff in allowing the court addressed to retain the proceedings) of the Spiliada test are relevant to the test under s 19 , as these are not explicitly recognised under in the list of factors contained in s 19(2)(a)(-(h), and therefore calling into question whether the s 19 test and Spiliada are actually similar. However there is scope for the court consider any other matter that it considers relevant under s 19(2)(i), and jurisprudence which has developed post inception of the legislation indicates that courts will likely consider a wide range of factors (including those relevant to element two of the test for a stay under Spiliada) under this broad catch-all. For example, in $R e$ Featherston, above n 85, at [53]-[54], it was noted that case law under the "more appropriate forum" test under s 20 of the Service and Execution of Process Act 1992 (upon which the s 19 test in the Trans-Tasman Proceedings Act 2010 (Cth) is based) has pertinently held that factors under element two of Spiliada will be relevant with reference to the inquiry of what is the appropriate forum to hear the dispute under that section (see also James Hardie \& Co Pty Ltd v Barry [2000] NSWCA 353 at [7]). In Re Featherston a similar approach with the more appropriate test in s 19 was expressly approved (at [53]-[54]).
} 
Australian legislation as well. If such a forum exists (which is considered under the first element of the test), and it is in the interests of justices for the dispute to be heard there, then a stay is granted. The current Australian approach under Voth, requires the court to only grant a stay where it considers that it is a clearly inappropriate forum to deal with the dispute. Other than the actual semantics of the test in Voth, ${ }^{92}$ conceptual differences between the two tests can be seen by comparing the circumstances in which a stay can be granted, and which highlight the forum biased approach of the current state of the law in Australia.

Under all three tests, the existence of an appropriate alternative forum to hear the dispute will usually be present. ${ }^{93}$ Where they differ is the significance this is given. Under Spiliada and s 19 , the role of the court is to consider whether there is a more appropriate forum to hear the dispute before a stay is granted. In contrast the test in Voth requires the court to ask whether "it" as the court addressed is a clearly inappropriate forum before a stay is granted. The mere fact that the court of another country would be a more appropriate forum for the particular proceeding to be heard in does not necessarily mean that the local court is a clearly inappropriate one. ${ }^{94}$

With reference to stay applications, this means that in some cases (where there was a strong argument that dispute is more closely connected with another forum), Australian courts have refused to grant a stay because they have ruled that, despite this strong connection, the Australian court was not a clearly inappropriate forum to hear the dispute. ${ }^{95}$ It is likely that if

\footnotetext{
${ }^{92}$ Which are patently biased towards retaining the proceedings - i.e. the test in Voth starts from the presumption that Australia is an appropriate forum to hear the dispute at it must be shown that is a clearly inappropriate forum before a stay will be granted. When applying such a test the court is therefore starting from the position that a stay should not be granted - see R Garnett, above n 68, at 35. The corollary is that the test is biased towards retaining proceedings because it is assumed the plaintiff's choice in commencing proceedings was the correct one, unless this is shown otherwise (logically by the defendant, although the formal evidential onus lies on the plaintiff, see footnote 74).

${ }^{93}$ It should be noted that the test in Spiliada and s 19 requires the existence of another more appropriate forum / court, before a stay can be granted. In contrast, the test under Voth (because it focuses on whether the court addressed is a "clearly inappropriate" one to hear the dispute, there is the potential the court could in fact rule itself a "clearly inappropriate forum" despite the absence of an alternative forum for the plaintiff to recommence proceedings, see Voth v Manildra Flour Mills Pty Ltd, above n 17, at 558). Taking a practical example, such a situation could arise where an action was time barred in a foreign jurisdiction but has no connection with the Australian forum. This facet of the test in Voth would potentially suggest that the test is in-fact biased towards the defendant's interest in forum, as there is the possibility under Voth that the Australian court would order a stay in circumstances which would deny the plaintiff any remedy. Under the Spiliada / s 19 tests this is not possible, as the court must be satisfied (before ordering a stay), that the "more appropriate forum" would have jurisdiction to hear the plaintiff's claim before ordering a stay. However, some Australian judges have suggested that such an outcome could "... only be contemplated in an extreme case" (see Henry v Henry, above n 82, at 578). This would again refute any argument this aspect of the test in Voth is in fact not "forum biased".

${ }^{94}$ Oceanic Sun Line Special Shipping Co Inc v Fay, above n 17, at 243

${ }^{95}$ See for example Al-Ru Farm Pty Ltd v Hedleys Humpers Ltd SASC, 10 January 1991, Phosphate Cooperative Company of Australia Ltd v SGS Supervision Services Inc SC 7 April 1993.
} 
these cases had been governed by Spiliada (or s 19) a stay would have been ordered, as all the factors relating to the defendant's liability arose in a foreign forum and there appeared to be little or no juridical advantage (e.g. Australian law allowed for the greater recovery of damages) for the plaintiff suing in Australia. The corollary is that under the current state of Australia's private international law with respect to forum non conveniens cases, little deference is given to the potential that an alternative forum would be more appropriate to hear the dispute, and in practice this has resulted in a significant number of these types of cases being retained by Australian courts. ${ }^{96}$ Compared to the common arrangements under the Trans-Tasman Proceedings Act 2010 (Cth), s 19, the test for a stay under Voth in forum non conveniens cases is clearly biased and demonstrates element three of the outer world problem is present.

(c) Exclusive Choice of Court Agreements

i. Introduction

The next category of cases which might arise with reference to the outer world problem is where there is an exclusive choice of court clause contained within the commercial contract at issue. Exclusive choice of court clauses should be further distinguished from non-exclusive choice of court clauses, as again the applicable test for resolving the issue of forum differs. ${ }^{97}$ An exclusive choice of court clause requires that the parties intended to confer jurisdiction on a particular court with respect to the dispute, but also to preclude any other court from exercising jurisdiction with respect to the dispute. ${ }^{98}$ A non-exclusive choice of court clause, by contrast, does not prevent a party from suing in an alternative forum. ${ }^{99}$ However despite

\footnotetext{
${ }^{96}$ James Hardie \& Co Pty Ltd v Cameron [1995] NSWDDT 5, James Hardie \& Co Pty Ltd v Bruce [1996] NSWDDT 6, Putt v James Hardie \& Co Pty Ltd [1998] NSWDDT 1, James Hardie Industries Pty Ltd v Grigor (1998) 45 NSWLR 20, Union Shipping New Zealand Ltd v Morgan [2002] NSWCA 124, James Hardie and Co Limited v Coyle [1998] NSWSC 190, Band B (Re Jurisdiction) [2003] FamCA 105.

${ }^{97}$ See R Garnett, above n 68, at 61-63.

${ }^{98}$ Ibid at 61.

${ }^{99}$ Ibid. The reason (other than the parties avoiding limiting their ability to commence proceedings in more than one forum) for including a non-exclusive choice of court agreement in a contract is to allow either party to sue on the contract in the forum to which submission is made to the jurisdiction, without being required to seek leave of the court addressed to serve proceedings on a defendant located outside of the jurisdiction or alternatively, any money judgment obtained by the defendant (even obtained in default of their appearance), is
} 
these different tests, the current state of Australian private international law remains biased towards retaining proceedings.

\section{ii. Akai}

In terms of cases where there is an exclusive choice of court agreement, ${ }^{100}$ the leading restatement of the applicable principles is the Australian High Court decision of Akai, which provides that unless there are strong reasons not to enforce the choice of court agreement, proceedings brought in breach of that agreement should normally be stayed, assuming the case is one in which a party has sought to challenge the clause (and vice-versa). ${ }^{101}$ As Garnett notes, this approach supersedes the "clearly inappropriate forum" test for a stay in Voth, and where the parties have agreed to an exclusive jurisdiction clause, the parties must show "strong reasons" or "exceptional circumstances" before a stay will be granted. ${ }^{102}$ In these circumstances "strong reasons" (or exceptional circumstances) has escaped a fixed judicial assessment, which has resulted in a significant amount of leeway being conferred on Australian courts as to when not to enforce such agreements. ${ }^{103}$ For example the Australian High Court has held in other cases that the court's discretion in this respect "... has not been restricted by any exclusive definition of the circumstances which will warrant refusal of a stay." 104 One of the more limited statements has set out a long list of factors which may guide the court's discretion but even then it has been emphasised that such a list is not exhaustive. ${ }^{105}$ The onus is on the party disputing the choice of court agreement. ${ }^{106}$

likely to be enforceable in most other countries, and in particular other common law countries where the defendant has already submitted to the jurisdiction of the court (see Goddard and McLachlan, above n 25, at 51).

${ }^{100}$ Mortensen, above n 2, at 80, Akai Pty Ltd v People's Insurance Co Ltd, above n 25, 418.

101 Ibid at 445, 447.

102 The difference in wording appears to be semantics, and arises because of the language used by English courts when considering whether to grant a stay where proceedings are brought in breach of a an exclusive choice of court agreement. Case law from England has been expressly approved by Australian courts considering a stay in this scenario, and therefore case law on what amounts to "exceptional circumstances" is relevant to the Australian test (see R Garnett, "The Enforcement of Jurisdiction Clauses" (1998) 21 UNSWLJ 1, at 9-10). ${ }^{103}$ A Bell "Jurisdiction and Arbitration Agreements in Transnational Contracts" (1996) 10 Jnl Contract L 53, at 61.

${ }^{104}$ Huddart Parker $v$ The Ship the Mill Hill (1950) 81 CLR 502 at 509.

105 See the below quote from the decision in The Eleftheria [1970] p 94 at 100:

"In exercising its discretion, the court should take into account all the circumstances of the particular case. In particular ... the following matters, where they arise, may properly be regarded: (a) In what country the evidence on the issues of fact is situated, or more readily available, and the effect of that on the relative convenience and expense of trial as between the English and the foreign courts. (b) Whether the law of the foreign court applies and if so, whether it differs from English law in any material respects. (c) With what 


\section{iii. Bias Under Exclusive Choice of Court Agreements}

On face value, there does not appear to be anything inherently biased about courts retaining a residual distraction to refuse a stay even where there is an exclusive choice of court agreement. ${ }^{107}$ However the manner in which this discretion has been exercised by Australian courts manifests a biased approach towards protecting the interests of local residents from being sued or forced to sue overseas. ${ }^{108}$ As noted earlier, this appears to have arisen largely from the wide discretion conferred on Australian courts when considering whether to refuse a stay. This extensive discretion retained by Australian courts has given them the ability to supposedly pay lip service to the importance of upholding an exclusive choice of court agreement, yet in practice refuse to order a stay in a wide-ranging set of circumstances.

For example, in Lewis Construction v Tichauer, an exclusive choice of court agreement was not enforced on the basis that the balance of convenience lay with requiring the dispute to be heard in Australia. ${ }^{109}$ There, the Supreme Court of Victoria had to consider an action by a Victorian company against a French company for breach of contract in relation to the supply of a defective crane. The crane had been built in France and then shipped to Melbourne where, after being installed, it fell, causing injuries to persons and property. The defendant applied for a stay of proceedings on the basis of the existence of an exclusive jurisdiction clause in the parties' contract. The parties had also made a choice of French law.

country either party is connected, and how closely. (d) Whether the defendants genuinely desire trial in the foreign country, or are only seeking procedural advantages. (e) Whether the plaintiffs would be prejudiced by having to sue in the foreign forum because they would: (i) be deprived of security for their claim (ii) be unable to enforce any judgment obtained (iii) be faced with time bar not applicable in England or (iv) for political, racial, religious or other reasons be unlikely to get a fair trial."

106 Owners of Cargo Lately Laden on Board Ship or Vessel Eleftheria v The Eleftheria (Owners) [1969] 2 WLR 1073.

${ }^{107}$ As Garnett notes, the rationale for this would appear to be that that parties could not oust the jurisdiction of the court merely by agreeing this to be the case, R Garnett, above $\mathrm{n} 102$, at 9 .

108 Ibid at 10. Cases can generally can be broken down into two categories: i) where the parties have elected a foreign jurisdiction (other than Australia) as the exclusive court to resolve their dispute and a stay is sought by the foreign party in their capacity as a defendant being sued in Australia and ii) the same scenario but where the party seeking the stay is a local Australian defendant (e.g. potentially in cases of lis pendens, where the Australian defendant has commenced proceedings in Australia based on say a counterclaim or set-off under the contract). For present purposes (the focus of the third element being on the foreign defendant, the party disadvantaged under outer world problem) the first category of cases will be used to illustrate the presence of element three of the outer world problem.

${ }^{109}$ Lewis Construction v Tichauer [1966] VR 341 (VSC). 
However, the court refused to grant a stay because, it was alleged the majority of evidence which would be relevant to the case was located in Victoria rather than France, and so trial would be much more convenient in Australia. The plaintiff would be subjected to a "positive injustice" if forced to litigate in France.

It is argued this decision gives insufficient primacy to the jurisdiction clause. This is particularly since it was exclusive, and highlights the earlier point, namely, that Australian courts have, at times, unduly sought to protect their residents from having to litigate overseas. The fact that important evidence was located in France and that the defendant would be deprived of a significant juridical advantage in not being able to join its supplier in the Victorian proceedings should have also been taken into account, and ultimately, decisive of the question of forum. The high probability that the court would be required to apply French law to resolve the dispute should also have been given greater significance. French law, being foreign, would have had to be proven by expert evidence before the court, to the significant cost of the parties and with the potential for error on the courts part.

As the reasoning in this case would demonstrate, the loosely prescribed discretion of Australian courts allows them significant freedom to ultimately rule that the exclusive choice of court clause is unenforceable and a stay should not be granted. This results in attempts by courts (as illustrated by the reasoning in Lewis), in overplaying factors which favour refusing to enforce the choice of court agreement, in order to justify the refusal of stay. Neither is the decision in Lewis an anomaly, in a number of similar cases stays have been refused based on the wide distraction with respect to enforcement and the paternalistic approach taken by Australian courts with reference to local Australian residents. ${ }^{110}$

Although Lewis was decided over two decades ago, subsequent case-law again demonstrates the propensity of Australian courts to retain proceedings brought in breach of a choice of court agreements. ${ }^{111}$ For example by 2008 , there was only an 11 per cent chance that an

\footnotetext{
${ }^{110}$ See for example Lep International v Atlanttrafic Express Service (1987) 10 NSWLR 614 (NSWSC), Gem Plastics v Satrex Maritime SC, 9 June 1995, Hopkins v Difrex Societe Anonyme [1966] 1 NSWR 979 (NSWSC). ${ }^{111}$ In the event the choice of court agreement dictates that Australia is the chosen forum, Australian courts are hardly likely to refuse to retain the proceedings based on the current state of its private international law, which would appear to be discriminatory to the foreign defendant when this is commonplace with respect to exclusive choice of court agreements which dictate a foreign forum as the designated court, see RA Brand and SR Jablonski, Forum Non Conveniens: History, Global Practice, and Future Under the Hague Convention on Choice of Court Agreements (Oxford University Press, 2007) at 100. Conversely in cases where the plaintiff is in breach of a choice of court of agreement, the high threshold for refusing stay only goes to further demonstrate
} 
Australian court would uphold a choice of court agreement that exclusively designated a foreign court for the litigation. ${ }^{112}$

\section{vi. Trans-Tasman Proceedings Act 2010 (Cth), s 20}

A useful comparison point to the Australian approach to exclusive choice of court agreements is their position under the TTPA. Under s 20 (as noted earlier), it is mandatory for the Australian court to order a stay (or refuse to order a stay), where the court is satisfied that an "exclusive choice of court agreement" designates New Zealand (or Australia) as the court to determine the matters in issue. ${ }^{113}$ It should be noted that a stay is mandatory, unless the provisos in s 20 are satisfied. ${ }^{114}$ An exclusive choice of court agreement must: ${ }^{115}$

a) designate the courts, or a specified court or courts, of a specified country, to the exclusion of any other courts, as the court or courts to determine disputes between those parties that are or include those matters; and

b) is not an agreement the parties to which are or include an individual acting primarily for personal, family, or household purposes; and

c) is not a contract of employment.

Section 20 is largely based off the provisions of the Hague Convention on Choice of Court Agreements, albeit that it only applies in the context of the TTPA. ${ }^{116}$ As Mortensen notes, the

the lengths Australian courts will go to retain proceedings - see M Keyes "Jurisdiction under the Hague Choice of Courts Convention: Its Likely Impact on Australian Practice” (2009) 5 J Priv Int L 181 at 199-200.

${ }^{112} \mathrm{M}$ Keyes, above n 111.

113 Trans-Tasman Proceedings Act 2010 (Cth), s 20.

${ }^{114}$ Section 20(2)-(2A). In cases where a New Zealand court is designated the court of choice, the Australian court may refuse to order a stay despite the existence of an exclusive choice agreement in the following circumstances:

a) it is null and void under New Zealand law (including the rules of private international law); or

b) a party to it lacked the capacity to conclude it under Australian law; or

c) giving effect to it would lead to a manifest injustice or would be manifestly contrary to Australian public policy; or

d) for exceptional reasons beyond the control of the parties to it, it cannot reasonably be performed; or

e) the court designated by it as the court to determine the matters in issue between the parties to the proceeding has decided not to determine those matters.

In cases where an Australian court is designated the court of choice, the Australian court may refuse to order a stay on the basis of the existence of an exclusive choice agreement where the Australian court is satisfied that the agreement is null and void under Australian law (including the rules of private international law).

115 Section 20(3).

${ }^{116}$ Convention on Choice of Court Agreements 2005 (done at The Hague 30 June 2005). See also TransTasman Working Group, Trans-Tasman Court Proceedings and Regulatory Enforcement: A Report by the 
Hague Convention is premised on two key principles, namely that when litigants are party to a choice of court agreement, they are generally (subject to very limited exceptions) required to litigate their dispute in the elected forum. ${ }^{117}$ Conversely, where the parties have brought proceedings in a member forum of the Convention, in breach of such an agreement, the court of that forum is generally required to stay the proceedings in favour of the court located in the member state the parties elected. The theme is self-evidently one of commitment to contractual commitments, and with a stronger expectation than the common law (as can be seen above) about the expectation that agreements about where to litigate are adhered to.

At a practical level this can be seen by comparing the exceptions at common law to the enforcement of an exclusive jurisdiction clause, as compared to those under the TTPA. The grounds under which an Australian court can refuse to grant a stay where the court is satisfied there is an exclusive choice of court agreement within the meaning of the legislation are heavily circumscribed. ${ }^{118}$ So for example, the court may refuse a stay on the basis that the agreement is null and void under the laws of New Zealand, which for example would include examples such as the contract itself was invalid, ${ }^{119}$ or was contrary to a statute. Lack of contractual capacity is also a stated ground. "Manifest injustice" (undefined) was not included in the Hague Convention, ${ }^{120}$ as an exception to enforcement of an agreement. This would appear to confer some residual discretion on the Australian court to refuse a stay, but the strong language used in the section is likely to mean that this discretion will rarely (if ever) be exercised in favour of issuing a stay. ${ }^{121}$ Similar reasoning is likely applicable to the "exceptional circumstances" beyond the parties control proviso (and again the reason the

Trans-Tasman Working Group (Ministry of Justice, December 2006) at 16. The Choice of Court convention was drafted at the Hague Convention of Private International Law (of which both New Zealand and Australia are members), however has not yet been ratified by either country. There are a number of key differences however, for example a number of exceptions to enforcement of an exclusive choice of court clause have been omitted from the TTPA, additionally different wording to the Convention article has been used, see Ronald A Brand and Paul M Herrup The 2005 Hague Convention on Choice of Court Agreements (Cambridge University Press, 2008) at 98-138. For present purposes this is largely irrelevant - it is argued that even the diluted form of s 20 (based on the Convention) is less biased than the current approach taken under Australian private international law.

${ }^{117}$ Moretensen, above n 2, at 80.

${ }^{118}$ Additionally the court must be satisfied that the dispute falls within the scope of the choice of court clause (see Trans-Tasman Proceedings Act 2010, s 20(1)(a)-(b)) - for example the clause may have been drafted narrowly to apply to only certain claims, or conversely, broadly drafted to embrace all claims arising from the contract.

${ }^{119}$ E.g. the absence of consideration, lack of intention to create a legal relationship, the contract was an illegal one (see the Illegal Contract Act 1970, s 7). Similar reasoning is likely to be applicable to the "null and void" exception vis a choice of court agreement which elects Australia as the designated court (see s 20(2A).

${ }^{120}$ Convention on Choice of Court Agreements 2005 (done at The Hague 30 June 2005), art 9(a)-(g).

${ }^{121}$ And is likely to be much more circumscribed than Australian court's current discretion with respect to the enforcement of choice of court agreement, although it is impossible to conclusively prove this until further jurisprudence has developed in the interpretation and application of $\mathrm{s} 20$. 
agreement should not be enforced would need to be beyond the parties control). The manifestly contrary to Australian public policy ground is likely to be interpreted according to how the phrase is used in other Hague Conventions, requiring a clear and serious breach of public policy before the agreement will be rendered unenforceable under s $20 .{ }^{122}$ The application of the final exception to enforcement of an agreement (that the designated court has refused to determine the matters at issue between the parties) is likely to cover situations where the designated court lacks jurisdiction, and therefore has resolved not to hear the matter. ${ }^{123}$

Compared to the wide ranging discretion present under Akai to refuse a stay, the grounds contained within s 20(2)-(2A) are relatively circumscribed when it comes to refusing to enforce an exclusive choice of court agreement to which the Australian legislation applies. For example, under s 20, the Australian court would be unable to refuse to enforce an exclusive choice of court designating a New Zealand court as the chosen forum, merely because it thinks that more of the evidence is located in Australia (to use the Lewis fact scenario). ${ }^{124}$ More importantly, the circumstances in which an exclusive choice of court agreement is unenforceable under s 20 are generally not aimed at allowing the court a "custodial" role in protecting the interests of one particular party over the other. This is a direct result of the circumscribed nature of the exceptions, namely an exhaustive list of grounds upon which enforcement might be refused. The result is that the potential for bias in the case of exclusive choice of court under the TTPA is heavily mitigated, and in general an Australian court will be required to enforce it and order a stay.

\section{v. Outer World Problem and Exclusive Choice of Court Agreements}

In terms of element three of the outer world problem, two arguments may be made as to why the Australia's private international law is biased with respect to exclusive choice of court

\footnotetext{
${ }^{122}$ See Brand and Herrup, above n 116, at 92-93, 117. Both Australian and New Zealand courts have generally been hesitant to utilise public policy exceptions to enforcement of legal rights - for example in the context of enforcing a foreign judgment see Marine Services Ltd v Bolton (1992) 6 PRNZ 173 (HC).

${ }^{123}$ For example, if the parties elected that the District Court of New Zealand was to have exclusive jurisdiction to hear the claim, but the claim was in excess of $\$ 200,000$. See District Court Act 1947, s 29.

${ }^{124}$ An argument would have to be made that this fits within the s 20(2)(c) (i.e. the manifest injustice exception) - again s 20 (despite seemingly maintaining some residual discretion to refuse to enforce an exclusive choice of court clause), sets the bar much harder than the strong reasons / exceptional circumstances test in Akai, meaning it will be much rarer for courts under the TTPA to be able to justify refusing to enforce an exclusive choice of court agreement on the ground that it results in hardship for one of the parties. Under the current state of Australian law, this is the norm rather than the exception.
} 
clauses. Firstly, in cases where the parties have elected that a foreign court should have exclusive jurisdiction to resolve their dispute, the current state of Australia's private international law means that it is highly likely that in the event a foreign defendant is sued in Australia (in breach of such an agreement), the court (under established case law) has wide discretion to refuse to grant a stay with reference to the strong reasons / exceptional circumstances proviso for refusing to enforce such a clause. In this scenario, despite earlier issues noted as to the presence of outer world problem in the case of international commercial contract disputes, it is clear that Australia's private international law takes an overly biased approach to exclusive jurisdiction clauses. Compared to the TTPA (where generally the parties choice of court is upheld subject to very few exceptions), Australia's private international law is biased towards retaining proceedings, even in the case of commercial contracts.

The second argument which can be made is that, even in cases where the foreign defendant has elected an Australian Court is the more appropriate forum; a degree of bias still arises. This is because, in contrast to the Australian local resident of the common market, an Australian court is much less likely to be willing to refuse to order a stay where the parties have elected Australia as the appropriate forum.

The focus of the earlier discussion was around the fact that bias arises generally because of Australian court's willingness to protect the interests of local residents over foreign defendants, as well as the wide discretion as to when a stay might be refused. This discussion was with reference to where the parties have elected that a foreign court as the court to resolve their dispute - but what of when they have chosen Australia in their exclusive choice of court agreement? On the one hand it might be argued that this counterbalances the bias alleged earlier, namely that even though Australian courts are generally unwilling to uphold an exclusive choice of court agreement with reference to foreign courts, a similar approach is taken to clauses which elect Australia as the court of choice.

Additionally it might be argued that (as noted earlier), the foreign defendant cannot be heard to complain of the private international law of the state addressed being biased, where it is merely giving effect to the ability of the parties to pre-regulate where disputes under the contract arise. However, this ignores the reality that the current state of Australian private international law, as a local resident of Australia has a strong possibility of arguing that (in 
the very same scenario), ${ }^{125}$ a stay should not be granted. There would appear to be a degree of unfairness in failing to consider whether foreign defendants can avail themselves of a similar juridical advantage.

The same legal test applies whether or not the forum elected in the choice of court agreement is Australia, or not. However the key difference is the approach Australian courts takes to the issue of a stay where Australia is the chosen court. Effectively the issue in this latter scenario is an institutional level bias towards retaining proceedings in Australia, seemingly based on a desire to protect local residents from being sued or having to sue abroad. ${ }^{126}$ Obviously it is difficult to prove this directly, but circumstantial evidence would indicate this is a fair assessment of the current state of Australia's private international law. Australian courts have a strong tendency to retain proceedings commenced within the jurisdiction, despite the fact that the dispute will often have a strong connection with another forum. ${ }^{127}$ The rationale for taking this approach can be seen by comparing it to cases where a foreign plaintiff has commenced proceedings in Australia against a local defendant. The approach of the Australian court in these cases (albeit the absence of an exclusive choice of court agreement), ${ }^{128}$ has generally been refuse to order a stay. ${ }^{129}$ The primary reason given by the courts has generally been that the local Australian defendant cannot seriously complain that proceedings commenced against them in their home jurisdiction should be stayed. It is difficult to conceive of what (if any) disadvantage or unfairness arises for the plaintiff in these circumstances. The unwillingness of Australian courts to grant stays in such cases would demonstrate that the impetus for the current bias under Australian private international law is attributable to the desire the courts have in protecting local residents from the costs, inconvenience, and (potential) juridical disadvantages from being forced to litigate overseas.

Accepting that this is the underlying rationale for Australian court's refusal to grant a stay in cases where there is a foreign exclusive choice of court agreement, it is unsurprising that

\footnotetext{
${ }^{125}$ Where the Australian resident party seeks to challenge the enforcement of an exclusive jurisdiction clause, the difference being that a foreign court has been selected in the exclusive choice of court agreement and a local plaintiff commences proceedings in Australia (in breach of such a clause) as compared to the scenario under discussion i.e. the parties have selected an Australian court in there exclusive choice of court agreement and the foreign defendant now seeks to challenge the enforcement of this clause.

${ }^{126} \mathrm{R}$ Garnett, above n 102, at 10.

127 See footnotes $62-134$.

${ }^{128}$ For present purposes this is irrelevant, the more relevant aspect of these cases is that they highlight Australian courts are often concerned with protecting local residents (which can still be seen despite the absence of an exclusive choice of court agreement in these cases).

${ }^{129}$ See R Garnett, above n 68, at 40, Banque Paribas v Jarrett SC, 25 July 1991, Prebble v Australian Broadcasting Corporation SC, 6 September 1996, James Hardie Industries Pty Ltd v Grigor, above n 96.
} 
there is not a single reported case where an Australian court has refused to enforce an exclusive choice of court clause which elected an Australian court as the forum of choice. ${ }^{130}$ Clearly this is because Australian courts are more concerned with protecting local resident's interests as opposed to those of foreign defendants. However it is also self-evidently biased and discriminatory.

In conclusion, it can be seen that despite the possibility for parties to pre-determine where any dispute is heard under their commercial contract, the large discretion conferred on Australian court to refuse to enforce an exclusive choice of court clause, and the inconsistent application of this discretion in the cases of foreign defendants illustrates the biased nature of the current state of Australia's private international law with reference to exclusive choice of court agreements. Compared to the arrangements under the TTPA (where primacy is given to enforcement of the exclusive choice of court agreement), it is clear element three of the outer world problem is present.

(b) Non-exclusive Choice of Court Agreements

The final type of fact scenario which may arise in the case of international commercial contracts is non-exclusive choice of court agreements. As noted earlier, such a clause does not exclusively bind the parties to litigate their dispute in one forum, however under established Australian case law, will be a relevant factor taken into account by the court when considering an application for a stay under Voth. ${ }^{131}$ However, under the current state of Australia's private international law, it will generally be a very rare case where a foreign defendant, who has agreed to a non-exclusive choice of court agreement (which confers jurisdiction on a local Australian court), is then able to obtain a stay of the local proceedings in favour of another forum. ${ }^{132}$ Again this appears to be systemic of the institutional level bias

\footnotetext{
${ }^{130}$ R Garnett, above n 102.

${ }^{131}$ Ibid at 2-3.

${ }^{132}$ For example, in Woolworths v D S McMillan SC, 29 February 1988, a New South Wales court refused a defendant's application for a stay in favour England, where both parties had agreed to "submit to jurisdiction of any competent court in the Commonwealth of Australia" and resolve any dispute "in accordance with the law and practice applicable in such court". The clause was interpreted to be a non-exclusive choice of court agreement and did not vest the local Australian courts with exclusive jurisdiction over any disputes that may have arisen between the parties. However the court argued it should be enforced since it was part of a freely negotiated commercial bargain. The court would therefore be frustrating the parties' intentions by not giving effect to the clause. This of course ignores the key point that it was not the intention of the parties that the Australian courts would have exclusive jurisdiction to resolve all disputes. The overplaying of this factor by the Supreme Court in Woolworths is a similar example of the approach taken by Australian courts with respect to
} 
present in the Australian court system. Under the Trans-Tasman Proceedings Act 2010, a non-exclusive choice of court agreement falls outside of the scope of the mandatory stay provision contained within s $20 .{ }^{133}$ Under s 19(2)(d) it is a factor the court is required to take into account when considering whether to grant a stay under s 17 / 19, on the basis that New Zealand is the more appropriate forum.

Under both the TTPA, and Australia's private international law, the existence of a nonexclusive choice of court agreement is a factor considered by the Court when considering the granting of a stay. However, based on the Supreme Court decision in Woolworths, commercial contractual disputes subject to Australian private international law (where a nonexclusive choice of court agreement submitting to the jurisdiction of an Australian court is present) will rarely (if ever) have a stay granted. ${ }^{134}$ Australian courts are much more likely to be willing to over-emphasise the use of such a clause as a factor justifying the refusal of a stay, when there may be other compelling factors pointing to the opposite outcome. However, when compared to the Trans-Tasman Proceedings Act 2010 (Cth), it is difficult to see how this particular issue is addressed. The "more appropriate court" test for a stay contained within s 19 does not provide any guidance on the balancing of factors (such as the existence of a non-exclusive choice of court agreement), against factors which point against a stay. Therefore an identical issue could foreseeably arise under the TTPA. This is especially so as it will be the same system of courts (Australian), albeit applying the test for a stay under s 19 rather than that provided for in Voth. Consequently element three of the outer world problem is not present in the case of non-exclusive choice of court agreements, as the TTPA does not appear to address the issue which has arisen under Australia's private international law (the willingness to use such an agreement as an overriding factor to refuse a stay).

\section{Streamlined Reciprocal Enforcement Regime}

exclusive choice of court agreements (i.e. overplaying particular factors in order to justify refusing to enforce such agreements). Invariably this will be to the foreign defendant's disadvantage, as the plaintiff will have served proceedings on the defendant (without leave of the court being required), in reliance of such a clause in Australia, and by agreeing to such a clause, the foreign defendant has likely invariably set themselves up to be required to defend proceedings in Australia, when the original intent of the agreement was to merely create this as a possibility.

133 Trans-Tasman Proceedings Act 2010 (Cth), ss 19(2)(d), 20(3).

${ }^{134}$ Even more rarely than under the "clearly inappropriate" test under Voth. 
(a) Overview

The final feature of the outer world problem is that the outer world judgment obtained under the private international law of the forum addressed within the common market becomes automatically enforceable within the common market. ${ }^{135}$ Moving to the New Zealand legislation an Australian civil judgment will become enforceable throughout the other Australian states, ${ }^{136}$ and New Zealand, subject to limited grounds of challenge. ${ }^{137}$ The TTPA provides for the enforcement of registrable Australian judgments, including a final and conclusive judgment ${ }^{138}$ that is given in civil proceedings by an Australian Court. ${ }^{139}$ A civil proceeding is a proceeding which is not a criminal proceeding. ${ }^{140}$ The definition obviously covers a judgment arising from a dispute under a commercial contract. A further caveat is that the registerable Australian judgment cannot relate to an excluded matter. These excluded matters do not relate to enforceability of a judgment relating to a contractual dispute. ${ }^{141}$ Assuming the judgment falls within the definition in section 54; the entitled party is required to apply to the registrar of the relevant court in the prescribed form in order to register the judgment within six years of the date of judgment. ${ }^{142}$

Once the registrar accepts registration of the Australian civil judgment, the entitled party is required to give notice in the prescribed form of registration to the liable party within 15 days from the date of registration, or a longer period on application to the relevant Court. ${ }^{143}$ On completion of registration and notice to all liable parties the judgment is deemed to be

\footnotetext{
${ }^{135}$ Mortensen, above $\mathrm{n} 2$, at $90-91$.

${ }^{136}$ See Mortensen, above $\mathrm{n} 2$, at 63, for the process of inter-state enforcement of judgments in Australia. Any issues which arise from the cross-border enforcement of an Australian civil judgment under its cross-vesting scheme isn't affected by the TTPA (the focus of this paper), but is worth remembering because the outer world judgment can also be enforced not only throughout New Zealand under the Trans-Tasman Proceedings Act 2010 (NZ) but in all the other states in Australia under the Service and Execution of Process Act 1992 (Cth) to the further prejudice of the foreign defendant.

${ }^{137}$ Trans-Tasman Proceedings Act 2010 (NZ), s 61, 68. See Goddard and McLachlan , above n 25, at 84-85.

138 That phrase is undefined in the Trans-Tasman Proceedings Act 2010 (NZ) (see s 4). It is likely that case law developed under the Reciprocal Enforcement of Judgments Act 1934 (NZ), ss 3(4) and 3A(5) (the previously applicable enforcement regime vis Australian civil judgements) would be applicable to the phrase as used under the Trans-Tasman Proceedings Act 2010 (NZ), s 54(1)(a). A judgment may be final and conclusive even where obtained in default of the defendant's appearance (Barclays Bank Ltd v Piacun [1984] 2 Qd R 476) or where subject to an appeal or an appeal is pending (Hunt v BP Exploration Company (Libya) Ltd [1980] 1 NZLR 104 (HC)).

${ }^{139}$ Sections 54(1)(a), 57.

${ }^{140}$ Section 4, definition of "civil proceeding".

${ }^{141}$ Section 4, definition of "excluded matter".

${ }^{142}$ Section 56, Trans-Tasman Proceedings Regulations and Rules 2013, regs 14-20.

${ }^{143}$ Trans-Tasman Proceedings Act 2010 (NZ), s 62, Trans-Tasman Proceedings Regulations and Rules 2013, reg 19.
} 
enforceable as if were a judgment of a New Zealand Court. ${ }^{144}$ The entitled party can then take enforcement steps under the applicable Court rules depending on the nature of the judgment, and the appropriate Court to commence enforcement proceedings. ${ }^{145}$

The definition of an Australian registrable judgment draws no distinction between whether the Australian civil judgment is one obtained in accordance with Australia's private international law or the Trans-Tasman Proceedings Act 2010 (Cth) (and the test under s 19). ${ }^{146}$ The definition focuses on the nature of the judgment and whether it is "final and conclusive", rather than the relevant scheme which resolved the issue of the most appropriate forum to hear the dispute.

(b) Automatic Enforcement

Use of the phrase "automatic enforcement" is potentially a misnomer, as the process above demonstrates, there are a number of administrative steps that must be taken before the Australian judgment can be enforced in New Zealand. Another key point to analyse is how enforcement of a registered judgment can be challenged. This is where efficiency of the enforcement regime arises, and correspondingly, where the unfairness of the outer world problem arguably arises under the TTPA.

Under section 61 of the Trans-Tasman Proceedings Act 2010 (NZ), the defendant may apply to set aside registration (and therefore the ability to enforce the), within 30 working days of receiving notice under s 57 (or a longer period if the leave of the New Zealand court is sought). ${ }^{147}$ The exclusive grounds upon which the defendant may challenge the registration of the judgment are as follows: ${ }^{148}$

\footnotetext{
${ }^{144}$ Trans-Tasman Proceedings Act 2010 (NZ), s 63.

${ }^{145}$ See Trans-Tasman Proceedings Act 2010 (NZ), s 64, High Court Rules 2009, Part 17 (Enforcement), District Court Rules 2014, Part 19 (Enforcement), Judicature Act 1908, s 16, District Court Act 1947, s 29.

${ }^{146}$ Trans-Tasman Proceedings Act 2010 (NZ), s 54. This will generally depend on the monetary sum sought under the judgment - the District Court has jurisdiction to enforce claims of up to $\$ 200,000$, whereas the High Court enforcement jurisdiction is uncapped in terms of the sum payable under the judgment.

${ }^{147} \mathrm{Ibid}, \mathrm{s} 61$. Additionally it should be noted that the defendant may seek a stay of enforcement of the registered judgment within a 15 day period once notified of registration, on the basis that they will be challenging the judgment in the original Australian court (see s 65).

${ }_{148}$ Section 61(1) provides that "This section specifies the only situations in which a New Zealand court in which an Australian judgment has been registered under section 57 may set aside the registration of the judgment."
} 
a) the judgment was registered in contravention of this Act; ${ }^{149}$ or

b) enforcement of the judgment would be contrary to public policy in New Zealand; or

c) both of the following subparagraphs apply: ${ }^{150}$

i. the judgment was given in a proceeding the subject matter of which was immovable property, or was given in a proceeding in rem the subject matter of which was movable property; and

ii. that property was, at the time of the proceeding in the original court or tribunal, not situated in Australia.

The key basis to challenging the registration is therefore that the enforcement of the judgment would be contrary to public policy. In this context historical case law which developed under section 6 of the Reciprocal Enforcement of Judgment Act 1934 (NZ) (which originally governed the question of enforcement of foreign judgments), is likely to continue to guide New Zealand courts in the context of s 61(2)(b). ${ }^{151}$ Under New Zealand case law, it has been highlighted that the public policy exception is a narrow one that involves notions of repugnance and matters that would "shock the conscience" of a reasonable New Zealander. ${ }^{152}$ It is not contrary to New Zealand public policy to enforce a foreign judgment merely because the cause of action upon which the judgment is based is not known to New Zealand law, nor where the outcome of the case would have been different under New Zealand law. ${ }^{153}$ The categories of cases where a foreign judgment would be unenforceable on the basis that it was contrary to public policy are not closed, however some pertinent examples from the cases include:

\footnotetext{
${ }^{149}$ See footnotes 136-146. Presumably this ground envisaged a situation where the Australian judgment had (by omission) been registered by relevant court registry staff in breach of the Act e.g. the judgment was not final or conclusive, or had not been registered in the prescribed form.

${ }^{150}$ This ground covers what is colloquially known as the Moçambique rule, from the House of Lords decision in British South Africa Co v Companhia de Moçambique [1893] AC 602 (HL). This rule provides hat a court generally has no jurisdiction to determine matters of title to, or possession of, immovable property (primarily land) located outside its jurisdiction. It's inclusion in the s 61 (as a basis for challenging enforcement) is based on the federal nature of Australia legal system -the Moçambique rule has been abolished by statute in New South Wales, and partially abolished in the Australian Capital Territory. However, it is applied in the other Australian States and Territories, and in New Zealand. Consequently it was kept in the legislation in order to recognise the (partial) divergence between the two countries in terms of the status of the Moçambique rule. Its application is relatively limited and would only prevent enforcement where the subject-matter of the judgment was the property itself (and that property was not located in Australia at the time of the original proceedings), rather than subsequent attempts to seek enforcement of a judgment sum against that property.

${ }^{151}$ Reciprocal Enforcement of Judgment Act 1934, s 6

${ }^{152}$ Lane v Questnet Ltd [2010] NZAR 210 (HC), Reeves v OneWorld Challenge [2006] 2 NZLR 184 (HC) at [67].

${ }^{153}$ Phrantes v Argenti [1960] 2 QB 19, Reeves v OneWorld Challenge, above n 152, at [56].
} 
a) a judgment was held unenforceable where a creditor had sought registration of a judgment for a sum in excess of lawful entitlement under the original judgment; ${ }^{154}$

b) a judgment was enforced where it had been irregularly obtained in the Solomon Islands (excessive damages award for breach of contract), albeit the defendant had absconded from the jurisdiction with the subject-matter of the dispute and the court addressed required him to purge his contempt prior to re-assessing the damages awarded; 155

c) a default judgment was enforced where it was alleged the defendant had not received adequate notice (in Hong Kong) of the proposed hearing date; ${ }^{156}$ and

d) a judgment was enforced where the liable party sought to have the judgment set aside on the basis that the current legal system of Fiji (where the judgement had been granted) was an unlawful one without credibility (having resulted from a military coup). ${ }^{157}$

As will be evident from the above examples, the public policy exception to enforcement has been interpreted relatively strictly in New Zealand, and a consistent theme in the cases above is the unwillingness of New Zealand courts to refuse enforcement in all but the most extreme of fact scenarios.

How then does this compare to the position prior to the inception of the Trans-Tasman Proceedings Act 2010 (NZ)? As noted earlier, the applicable legislation for the enforcement of Australian judgements was the Reciprocal Enforcement of Judgment Act 1934. ${ }^{158}$ Compared to that Act, the Trans-Tasman Proceedings Act 2010 (NZ) jettisons almost all the familiar private international law criteria for enforcement of judgments in the Trans-Tasman context. In particular, there is no jurisdiction requirement, ${ }^{159}$ and the only defence to

\footnotetext{
${ }^{154}$ Dymock v Bilbie (1999) 13 PRNZ 158 (HC).

${ }^{155}$ Bolton v Marine Services Ltd, above n 122.

156 Lane v Questnet Ltd, above n 152.

157 Abe v Azim HC Auckland CIV 2010-40403741, 4 April 2011.

${ }^{158}$ Australian judgments were treated as any other foreign judgment prior to the Trans-Tasman Proceedings Act 2010 (NZ), see Mortensen, above n 2, at 62-66. Australian judgments can also be enforced at common law in New Zealand (see Goddard and McLachlan, above n 25, at 58-68). For present purposes it is sufficient to note that the Reciprocal Enforcement of Judgment Act 1934 (NZ) (to a large extent) codified the common law principles relating to enforcement of foreign judgments in New Zealand, and provided a streamlined procedural process for enforcement where New Zealand had reciprocal enforcement arrangements in place with the forum which issued the judgment e.g. under the Act, separate proceedings to sue on the judgment do not need to be initiated, whereas at common law the entitled party had to sue on the judgment as a new cause of action (see Goddard and McLachlan, above n 25, at 70).

${ }^{159}$ Under the Reciprocal Enforcement of Judgment Act 1934, a foreign judgment could only be enforced where the original court had jurisdiction to hear the case (s 6(1)(b). Section 6(3)(a)-(c) sets out a list of circumstances when the foreign court will be deemed to have jurisdiction for the purposes of enforcement under the Act e.g.
} 
enforcement is that enforcement would be contrary to public policy (in the narrow sense discussed above). ${ }^{160}$ The basic idea is that any issues the judgment debtor wishes to raise in relation to jurisdiction, natural justice, or fraud, should be raised in the original court rather than the enforcement proceedings. Therefore an Australian civil judgment, which was obtained under the domestic private international law of Australia, becomes readily enforceable throughout New Zealand against the assets of the foreign defendant, in circumstances where the defendant has been unable to avail themselves of the "more appropriate court" test in s 19 of the Trans-Tasman Proceedings Act 2010 (Cth). ${ }^{161}$

\section{The Outer World Problem: A Problem at All?}

\section{A Introduction}

It is relatively clear that the outer problem is present under the TTPA scheme. The question then becomes, is it actually problem? This requires a clear articulation of where unfairness arises under the outer world problem, and, to what extent counter arguments balance this unfairness. Accordingly, it is logical to address these issues with reference to the parties and their perspectives on the to the outer world problem. ${ }^{162}$ Ultimately it is argued that a

submitting to the jurisdiction through voluntary appearance in the proceedings, or if the defendant was also a plaintiff or counterclaimed in the original proceedings, see Goddard and McLachlan, above $n$ 25, at 77-80). In contrast, the Trans-Tasman Proceedings Act 2010 (Cth) does not specify any jurisdictional requirements before the foreign judgment can becomes enforceable in New Zealand, in the case of foreign defendants. As noted earlier, the legislation makes no distinction as to whether the streamlined enforcement process applies under the Act, with reference to how the court issuing the judgment determined what the appropriate forum was to hear the dispute prior to issuing the judgment (i.e. whether this was assessed under Australia's private international law or section 19 of the Trans-Tasman Proceedings Act 2010 (Cth)).

${ }^{160}$ Compare Trans-Tasman Proceedings Act 2010, s 61(2)(a)-(c).

${ }^{161}$ See footnotes $57-61$.

162 The states interest in the outer world problem (i.e. Australia and New Zealand) are of course relevant, but in the present case is difficult to ascertain as at an institutional level there appears to have been a complete failure to consider the implications of the enforcement regime applying to judgments against non-market parties (see Trans-Tasman Working Group, Trans-Tasman Court Proceedings and Regulatory Enforcement: A Report by the Trans-Tasman Working Group (Attorney General's Department (Australia) Ministry of Justice (New Zealand), December 2006) at 7-8, Trans-Tasman Working Group, Trans-Tasman Court Proceedings and Regulatory Enforcement: A Public Discussion Paper by the Trans-Tasman Working Group (Attorney General's Department (Australia) Ministry of Justice (New Zealand), August 2005), at 1, Trans-Tasman Proceedings Bill 105-2 (select-committee report) at 1, (23 March 2010) 661 NZPD 9702, (18 March 2010) CAPD 2215 (Cth)). In fact it is likely that under established private international law principles such as international comity, both Australian and New Zealand governments should have refused to support an initiative which purports to allow one state in the common market to exercise excessive jurisdiction against foreign nationals and then enforce any resulting judgment freely throughout the common market, as such an initiative fails to recognise that Australian courts cannot have unlimited jurisdiction, as this offends the sovereignty and interests of other nations and the 
significant degree of unfairness arises for the defendant, and that this is not outweighed by counter-arguments about the benefits the current state of the law has for plaintiffs.

\section{B The Foreign Defendant's Perspective}

How then does the issue of unfairness arise towards foreign defendant under the outer world problem? The issue of the outer world problem obviously necessitates some assumptions, because of the interrelating steps via which the problem is manifested. ${ }^{163}$ These are outlined below:

a) it is assumed that a common market plaintiff has commenced proceedings against a non-common market defendant in an Australian court;

b) it is assumed the dispute between the parties has a close connection with another dispute, in that it strongly arguable that it should be heard in that forum;

c) it is assumed that the Australian court retains the proceedings despite an application for a stay, and then enters judgment in favour of the plaintiff; and

d) it is assumed that the foreign defendant has assets in New Zealand as well as Australia.

In the above scenario, at a practical level, the issue for the foreign defendant is clearly one of enforcement of the Australian judgment, which can be easily and quickly enforced in New Zealand, subject to few grounds of challenge. This allows the plaintiff to quickly access assets of the foreign defendant which are present in both Australia, and more importantly, New Zealand under the Trans-Tasman Proceedings Act 2010 (NZ). There is nothing inherently unfair about this, on the face of it. As Mortensen notes, the rationale for expedited enforcement of foreign judgments is to reduce economic barriers to trade through reciprocal arrangements between the states located within the common market. ${ }^{164}$ This is able to occur

principle of international comity (see Gray, above n 39, at 209, Collins, above n 73, at 5-6). If the scheme did not apply to the resulting judgment, then arguably this does not offend the principle of comity as before the resulting judgment could be enforced in New Zealand, the plaintiff would need to establish that the Australian court had proportionate jurisdiction (within the meaning of s 6 of the Reciprocal Enforcement of Judgments Act 1934) to hear the claim before enforcing any resulting judgment.

${ }^{163}$ For example, it is not guaranteed that in a case where the Australian court retains the proceedings, judgment will be entered in favour of the plaintiff. However one of the key issues under the outer world problem is the enforcement of the judgment within the common market. This merely illustrates the multiple steps of the problem, and on the likelihood of it occurring.

${ }^{164}$ See Reid Mortensen, “Autochthonous Essential: State Courts and a Cooperative National Scheme of Civil Jurisdiction” (2003) 22 U Tas LR 109, at 109. 
because the states located within the common market can have confidence in the level of justice which will be obtained by the parties in other states, particularly with respect to the issue of jurisdiction exercised by other states within the common market: ${ }^{165}$

“... a willingness to let court' judgments 'circulate' freely over internal borders in a multistate area also suggests confidence that those courts exercise proportionate civil jurisdictions that are acceptable..."

To what extent then (from the foreign defendant's perspective), can they have confidence that a judgment obtained in Australia was based on a "proportionate" exercise of civil jurisdiction? The answer would appear to be little, if any. Jurisdiction in this context includes not only the ability of the court to hear and determine the matter at issue between the parties, but also order a stay on the basis that the dispute is more closely connected with some other forum. ${ }^{166}$ The highlights of the earlier review include that:

a) in general, Australian courts are much more willing to retain proceedings commenced within the jurisdiction against a foreign defendant, even where there is a strong argument the dispute is more closely connected with another forum. Conversely they are much less willing to grant a stay in such circumstances; ${ }^{167}$

b) in forum non conveniens cases, the clearly inappropriate test in Voth starts from the presumption that Australia is an appropriate forum to hear the dispute, and requires the court addressed to effectively ignore the appropriateness of another forum which may be more closely connected with the dispute, to the disadvantage of the foreign defendant; ${ }^{168}$

c) in exclusive choice of court agreement cases, the wide residual discretion to refuse a stay under Akai, and the institutional level bias which is seemingly apparent in the Australian judiciary will generally mean that in cases where the agreement dictates a foreign court as the chosen forum, Australian courts will refuse to grant a stay if an Australian plaintiff commences proceedings in Australia. Conversely, foreign defendant's are unlikely to be able to avail themselves of a similar discretion when it

\footnotetext{
165 Ibid.

${ }^{166}$ In the context of Australia this would include provisions in court rules which allow for service outside of the jurisdiction, as well as established forum non conveniens principles such as the "clearly inappropriate" test for a stay in the Australian High Court decision in Voth v Manildra Flour Mills Pty Ltd.

${ }^{167}$ Footnote 62.

168 Footnotes 93-96.
} 
comes to challenging an exclusive choice of court clause dictating Australia as the more appropriate forum; ${ }^{169}$ and

d) in non-exclusive choice of court agreement cases, such clauses are likely to be determinative of the issue of a stay, with Australian courts using a submission clause as an overriding factor to refuse granting a stay, despite the fact such a clause is one factor to be considered in all the circumstances of the case. Anomalously, a similar approach is not taken where an Australian resident has submitted to the jurisdiction of a foreign court. ${ }^{170}$

The concept of proportionate civil jurisdiction underlies the hesitancy of one state to enforce the judgments of another, namely that one court will only wish to enforce the judgment of another in circumstances where it would have also entertained the claim. And the exercise of proportionate jurisdiction highlights one of the key underlying themes of private international law, namely, that the law should ensure the legitimate expectations of the parties are met when it comes to the question of where their legal dispute are resolved. ${ }^{171}$ In the present context, it is unfair for the judgment to be enforced throughout the common market because it is obtained under a legal regime (i.e. the private international law of Australia) which is patently biased towards retaining proceedings commenced within that jurisdiction. It is unfair because the basis upon which enforcement can occur under the Trans-Tasman Proceedings Act 2010 (NZ) is the private international law of Australia, which is self-evidently not proportionate when compared to the arrangements made for disputes which fall within the scope of the TTPA scheme.

To a large extent the relevant legal tests under Australian law (as summarised above) fail to account for the interests of the foreign defendant in where the dispute has heard, and ultimately, ensure that the possibility of judgment being handed down in Australia will then becoming speedily enforceable in New Zealand under the Trans-Tasman Proceedings Act 2010 (NZ). The unfairness therefore arises from the circumstances of enforcement, ${ }^{172}$ and the

\footnotetext{
${ }^{169}$ Footnotes 97-128.

${ }^{170}$ Footnotes 131-134. It should be noted that non-exclusive choice of court agreements fall outside of the scope of the outer world problem, as element three is not satisfied (i.e. compared to the TTPA arrangements, it is unclear that a different outcome in terms of a stay would be achieved, especially in light of the paternalism towards protecting local plaintiff's interest, shown by Australian courts). However this fact scenario is still worth mentioning as it corroborates the point being made, namely Australian courts have a tendency to exercise excessive civil jurisdiction over non-Australian defendants.

${ }^{171}$ Collins, above $\mathrm{n} 73$, at $4-5$.

${ }^{172}$ I.e. where the Australian court has exercised excessive jurisdiction (e.g. retaining a case where there is little to no connection with Australia, and ignoring or failing to adequately take account of the foreign defendant's interests in having their dispute heard in another forum).
} 
discriminatory treatment of the defendant. The TTPA regime is clearly discriminatory, as it applies different tests based on the nationality of the defendant when it comes to the issue of jurisdiction (thereby disadvantaging them), yet fails to take this into account when it comes to the question of enforcing the resulting judgment. ${ }^{173}$ Put another way, it does not appear to be unfair to expect that a foreign defendant who is served with proceedings in Australia is able to avail themselves of the more proportionate test under s 19 of the Trans-Tasman Proceedings Act 2010 (Cth), if any resulting judgment will be enforceable in New Zealand under the Trans-Tasman Proceedings Act 2010 (NZ).

Again at a practical level, unfairness can be seen by identifying that in some cases (involving a foreign defendant), if the dispute had been subjected to a different test (e.g. Spiliada, or s 19 of the Trans-Tasman Proceedings Act 2010 (Cth)), the dispute may well have never been retained by the Australian courts, with the result that the plaintiff would have been required to seek judgment elsewhere (with the resulting judgment not being automatically enforceable in New Zealand). ${ }^{174}$ This would all appear to be palatably unfair to the foreign defendant, with little justification other than the benefits obtained by the plaintiff.

\section{Plaintiff's Perspective}

The plaintiff's perspective of the outer world problem is obviously a positive one. Again this is the corollary of the ease in which they may access the assets of the defendant in New Zealand. Consequently, suing in Australia may be seen as a juridical advantage for the plaintiff, as under the Trans-Tasman Proceedings Act 2010 (NZ), they will be able to easily enforce any resulting Australian judgment under that legislation in New Zealand, and thereby access any assets the defendant has in New Zealand (in addition to those located in Australia).

\footnotetext{
${ }^{173}$ For example the ICCPR provides in article 26 that "All persons are equal before the law and are entitled without any discrimination to the equal protection of the law. In this respect, the law shall prohibit any discrimination and guarantee to all persons equal and effective protection against discrimination on any ground such as race, colour, sex, language, religion, political or other opinion, national or social origin, property, birth or other status (emphasis added)." see International Covenant on Civil and Political Rights GA Res 2200A XXI (1966), art 26. Arguably the TTPA is discriminatory in this sense as it does not treat parties equally, discriminating as to whether the party is local to the common market or not.

${ }^{174}$ As Garnett notes, there is a strong possibility in many of the Australian forum non conveniens cases, a different outcome may well have resulted if the court had applied a more balanced test (e.g. the Spiliada test for a stay), see R Garnett, above $\mathrm{n} 68$. Similar points may be made with reference to the current state of law with reference to choice of court agreements.
} 
The case is clearly one of forum shopping then, namely the plaintiff's perspective of the outer world problem is that the ability to sue in Australia and utilise the reciprocal enforcement regimes present between the two countries is a logical advantage of suing in Australia, and the plaintiff should not be criticised for this. ${ }^{175}$ The advantage is that any resulting judgment will be easily and quickly enforceable in New Zealand, as well as Australia. Conversely, if the plaintiff had sued in another forum, any judgment would have had to have been enforced in New Zealand, at common law or under the Reciprocal Enforcement of Judgments Act 1934. In assessing the alleged unfairness for the defendant, this must be balanced against the advantages the current state of the law provides the local plaintiff.

To a large extent, whether the plaintiff's perspective is justified depends on ones view on forum shopping. One of the key issues that most academics identify with forum shopping is that the outcome of a case should not vary depending upon which forum it is litigated in. ${ }^{176}$ This is the case under the TTPA (i.e. if proceedings were litigated in other forum, then the expedient process for enforcement of the Australian judgment in New Zealand combined with the high probability that proceedings would be retained if commenced in Australia would potentially not be present in another forum). Juenger makes the point that such an argument is absurdly premised on the idea that all states and nations adopt a uniform system of private international law for allocating disputes. ${ }^{177}$ Juenger argues that the focus on attaining "decisional harmony" (or uniformity) detracts from what should be the key focus of private international law, namely furthering the ends of material judgment. ${ }^{178}$ This point is accepted, but as Lord Denning once aptly said, in the context of forum shopping for personal injury claimants in America; "The Plaintiff holds all the cards." ${ }^{179}$ Extrapolating this comment to apply to forum shopping as a concept more generally, it is the plaintiff's interests whom are materially furthered, as they can elect which forum to commence proceedings in, with the defendant always being required to react. In some cases allowing a plaintiff to forum

\footnotetext{
${ }^{175}$ See The Atlantic Star [1973] 1 QB 364 at 381-382, per Lord Simon Glaisdale ““'Forum-shopping” is a dirty word; but it is only a perjorative way of saying that, if you offer a plaintiff a choice of jurisdictions, he will naturally choose the one in which he thinks his case can be most favourably presented: this should be a matter neither for surprise nor for indignation."

${ }^{176}$ Juenger, above $\mathrm{n} 30$, at 6 .

${ }^{177} \mathrm{Ibid}$ at 7 . The point being made here is that the divergence in different private international law rules for issues such as characterisation (i.e. classifying the legal relationship for the purpose of determining the appropriate forums law to apply to them), and connecting factors (i.e. ascertaining which forum has the closest connection with the dispute), and how common this is across many jurisdictions, highlights the illusory nature of hope for world-wide agreement, for the purpose of discouraging forum shopping. Consequently dismissing forum shopping as a disreputable practice which should be discouraged by the law is naïve as it presupposes that global law will one day be in a position to obviate its need, when all evidence points to the contrary.

${ }_{178}$ Ibid at 11.

${ }^{179}$ Smith Kline \& French Laboratories Ltd v Bloch [1983] 2 All ER 72 at 74 (CA).
} 
shop may be laudable, but it is submitted that it must always be balanced against the interests of both parties to a legal dispute rather than just one (i.e. the plaintiffs).

A greater need to balance the party's interests is clearly needed in the case of the outer world problem under the TTPA. The plaintiff is able to commence proceedings in Australia, and even where the dispute has a strong connection with another forum, ultimately have those proceedings retained even where there is a strong argument the dispute is more closely connected with another forum. This is a direct result of the current state of Australia's private international law and the inapplication of the forum allocation test in s 19 of the TransTasman Proceedings Act 2010 (NZ). The outcome is that the resulting judgment is then enforceable relatively easily and with little scope for challenge throughout the common market. One might say this furthers the interests of the plaintiff, but can it be said that it furthers the interests of justice? Such a one-sided view of forum shopping (and the outer world problem) is unacceptable.

For example is it so detrimental to the interests of the plaintiff to require it to litigate disputes in a forum where it had agreed to litigate the dispute, had submitted to the law of that jurisdiction, and where most of the evidence was located? ${ }^{180}$ The common theme under Australian private international law is that Australian plaintiffs are often not required to litigate disputes in forums which are (objectively) much more closely connected with their dispute. It would appear to be positively fair to require them to litigate disputes in such a forum. In terms of the question of the enforceability of any judgment obtained in that forum, the party would then likely to be required to enforce the foreign judgement under s 6 of the Reciprocal Enforcement of Judgment Act 1934 or at common law. ${ }^{181}$ One of the key requirements would be that, under s 6 , the court had jurisdiction to hear the parties' dispute. ${ }^{182}$ Ironically there is no such requirement under the TTPA with respect to judgments obtained against foreign defendants, despite the underlying rationale of a reciprocal judgment enforcement scheme (which is that the court enforcing the judgment can have confidence that it would also have heard the claim which resulted in judgment). ${ }^{183}$ It is ironic because the TTPA is predicated on this principle - this can be seen from the uniform jurisdictional test for forum allocation contained in s 19 of, so that the New Zealand court can have confidence in

\footnotetext{
180 The example used here is from the earlier decision of Lewis Construction v Tichauer, above n 109.

${ }^{181}$ Goddard and McLachlan , above n 25, at 68-88

182 Reciprocal Enforcement of Judgment Act 1934, s 6(1)(b), Goddard and McLachlan, above n 25, at 68-88.

${ }^{183}$ See footnote 165 . The point being made here is that the drafters of the TTPA scheme gave no thought to the issue of how non-common market resident disputes (or where one party is a non-resident) would fit into the scheme of the TTPA, see materials cited at footnote 29.
} 
enforcing any resulting Australian judgment. ${ }^{184}$ But as has been argued, this does not apply in cases where one of the parties is a foreign defendant.

When viewed this way, there would appear to be a compelling argument that the plaintiff should not be entitled to the advantage of being able to enforce a judgment in New Zealand which resulted from a different jurisdictional test to that contained within the common market arrangement. The position of enforcement of a judgment which resulted from the s 19 test in the Trans-Tasman Proceedings Act 2010 (Cth), and under the private international law of Australia is not analogous because the former creates a more proportionate jurisdiction whereas the latter is not. This undermines the entire purpose of establishing a uniform test for jurisdiction under the scheme (which is to facilitate inter-state confidence about the nature of cross-border judgments being enforced), as well as causing a palatable unfairness to the foreign defendant. Ultimately it would appear to be better to focus on more complex analysis of these advantages rather than taking broad principled based arguments (such as those raised by Juenger) with reference to forum shopping. Although valid arguments, they fail to address the specific issues raised by the outer world problem and whether the plaintiff should be entitled to forum shop for such advantages. Ultimate it is argued the plaintiff's perspective should does not impact on the significant unfairness which arises for the defendant under the outer world problem.

\section{Choice of Court Agreements}

The final point with reference to fairness to the defendant under the outer world problem is the issue of choice of court agreement, where the dispute involves a commercial contract. This issue can be dealt with relatively quickly. The argument (as discussed somewhat analogously in the context of whether Australia's private international law is biased), would be that the defendant cannot seriously complain of any juridical advantage the plaintiff can obtain as a result of suing in Australia, where they have elected this as the exclusive forum to hear any dispute arising under the contract. However, this ignores the reality of the current state of Australia's private international law and the different types of clauses which can be used in a commercial contract.

${ }^{184}$ See Mortensen, above n 2, at 90-91. 
Where there is an exclusive choice of court agreement dictating Australia as the chosen forum, foreign defendant's will generally be unable to avail themselves of the wide discretion allowing the court to refuse to enforce such agreements because of the paternalistic approach Australian courts take to protecting the interests of local residents from being required to sue or be sued abroad. ${ }^{185}$ In cases where the exclusive choice of court agreement dictates a foreign forum as having exclusive jurisdiction, there is a strong possibility that the court will refuse to enforce it. ${ }^{186}$ The result is that any argument that it is fair to expect the defendant to live with the consequences of electing Australia as the appropriate forum in a choice of court agreement (e.g. the ability for their assets in New Zealand to be expediently seized by the plaintiff) are countered by the fact that the current state of Australia's private international law is discriminatory. If the foreign defendant was a local resident, there is a strong possibility they would be judicially assisted in escaping from their earlier bargain to litigate any dispute arising under the contract in Australia. Conversely in the very case where the defendant has elected a foreign forum, which will supposedly avoid them being subjected to this particular procedural disadvantage, an Australian court will likely refuse to enforce the agreement. The outcome is that cannot seriously be said to be fair to require the defendant to accept enforcement against its assets in New Zealand, where the treatment of the relevant agreement is either discriminatory, ${ }^{187}$ or in other cases generally rendered unenforceable. ${ }^{188}$

\section{Conclusion and Reform}

\section{A Introduction}

Accepting that the outer world problem is in fact "a problem", the logical question then becomes, what is the solution? A wide-canvassing discussion in potential reform options is beyond the scope of this paper but some potential options are discussed briefly below, as well as potential difficulties that would arise with such a solution to the outer world problem. This

\footnotetext{
185 See footnotes $125-130$.

186 See footnotes $97-124$.

${ }^{187}$ I.e. where the parties have elected Australia as the chosen forum in their choice of court agreement.

${ }^{188}$ I.e. where the parties have elected a foreign forum as the chosen place to litigate their dispute. As noted earlier non-exclusive choice of court agreements have been omitted from the present discussion as they arguably do not fall within the definition of the outer world problem (see footnotes 131-134).
} 
has also been done specifically with reference to the issue of commercial contractual disputes as well.

B Amend the Trans-Tasman Proceedings Act 2010 (Cth), s 19

The current unfairness to the defendant under the TTPA and the outer world problem arises because the proportionate jurisdictional test in s 19, does not apply unless both the parties are common market parties. Enforcement of the resulting judgment in New Zealand (the practical reason the foreign defendant is concerned with the outer world problem) is ancillary, as it is effectively the circumstances of the judgments enforcement which is where the real unfairness arises. ${ }^{189}$ Consequently, one potential solution could be to reform the TransTasman Proceedings Act 2010 (Cth) / (NZ), ${ }^{190}$ so that applications for a stay govern both cases involving common market parties, as well as cases where one (or even both) parties are located outside of the common market. This would mean any resulting judgment was obtained under a significantly more proportionate jurisdictional test than that currently in place under the Australian test in Voth, and would remove any claim the foreign defendant could make that they have been treated unfairly when such a judgment becomes readily enforceable throughout the common market.

A number of issues arise with this solution. Firstly, the underlying purpose of the Christchurch Agreement was (despite some confusion around terminology) to establish a reciprocal enforcement judgment regime for disputes between common market parties. ${ }^{191}$ Although this point is somewhat complicated by the Trans-Tasman Working Groups refusal to adopt the Brussels model used in the European Union (i.e. limiting the application of the cross-enforcement scheme to those domiciled within the common market), and the focus placed on service rather than some other connecting factor or concept, it is clear that the

\footnotetext{
189 The judgment having resulted from an Australian court exercising excessive jurisdiction.

190 The focus of this paper has been on the outer world problem as it arises from proceedings commenced in Australia, with the resulting judgment being then enforced under the Trans-Tasman Proceedings Act 2010 (NZ) (see footnote 42). Arguably the problem does not arise in New Zealand under its current law (the more proportionate test in Spiliada), however the author has not extensively reviewed the relevant case law with respect to choice of court agreements and their position under New Zealand law. Common law countries are notorious for their forum biased approach to cases where proceedings have been served out of the jurisdiction (see Gray, above n 39, at 208-209), therefore the better approach (and consistent with the reciprocal nature of the TTPA scheme) would be to reform both pieces of legislation consistently to apply to cases heard in Australia and New Zealand. References to the Australian legislation should also be read as referring to the equivalent provision in this discussion of reform.

${ }^{191}$ See footnote 29.
} 
intention behind the TTPA scheme was to limit its application to parties that had a close connection with Australia or New Zealand. ${ }^{192}$ Consequently amending the legislation to apply to non-common market parties would appear to fly in the face of the underlying purpose of scheme, albeit there appears to be no legal reason for this to not be possible. ${ }^{193}$ An additional concern would be clearly articulating the scope of the application of the test in s 19, and this is especially so in light of the Trans-Tasman Working Group's refusal to use concepts such as domicile or residence. ${ }^{194}$ One potential solution could be to provide s 19 governs cases for a stay where the foreign defendant is served outside of the common market. This would remove any incentives for the defendant to be served within or out of the common market, ${ }^{195}$ although the wording in s 17 and s 19 would need to be amended to make it clear that the court could order a stay in favour of not only an Australian or a New Zealand court, but any other forum the foreign defendant wished to argue was the more appropriate court to hear the dispute. Another issue (one which will not be addressed until further case law has developed), is whether Australian courts will continue their biased approach to applications for a stay under ss 17 / 19 of the Trans-Tasman Proceedings Act 2010 (Cth). This may well be possible, as the test is for a stay under s 17 / 19 is effectively a discretionary one with a number of factors being listed in section 19 and it being left up to the court how they are weighed up in any given case.

C Realign the Private International Law of Australia and New Zealand

Another solution could be to mandate the application of the test for a stay, as provided for in the House of Lords decision in Spiliada, under Australian private international law. This would require either judicial over-ruling by the Australian High Court of the test from Voth,

\footnotetext{
${ }^{192}$ See footnotes $29,42-61$. This would also seem to be relevant when arguing whether judgments against noncommon market residents falls within the scope of the expedited enforcement regime under the TTPA, however as noted earlier (see footnote 146) the legislation makes no distinction as to the party against whom the judgment is made and it would effectively require additional words to be read into

${ }^{193}$ It would also be likely that such a solution would be rejected by both Australian and New Zealand governments due to the absence of reciprocal enforcement arrangements with many other foreign nations, on the basis that they may well not have similar propionate tests for exercising jurisdiction over non-residents.

${ }^{194}$ Trans-Tasman Working Group, Trans-Tasman Court Proceedings and Regulatory Enforcement: A Public Discussion Paper by the Trans-Tasman Working Group (Attorney General's Department (Australia) Ministry of Justice (New Zealand), August 2005)

${ }^{195}$ Currently serving the defendant outside of the common market means the Trans-Tasman Proceedings Act 2010 (Cth), s 19, will not apply to the dispute and it will be governed by the private international law of Australia. This creates an incentive for the plaintiff to serve proceedings outside of the common market as when the defendant has to seek a stay it is not possible for them to make an application under the Trans-Tasman Proceedings Act 2010 (Cth), ss 17, 19.
} 
or legislative abolishment. This would again address the issues around excessive jurisdiction and the resulting circumstances of enforcement and fairness for the foreign defendant, as the Australian court would be required to apply a much more proportionate jurisdictional test than that currently provided for under Australian private international law. This would also avoid issues around amending the TTPA scheme to apply to non-common market defendants discussed above, and would also seem to address the underlying cause of the outer world problem under the TTPA scheme, which is Australia's private international law. ${ }^{196}$ Again this solution does not address issues that under Spiliada, the wide discretion (in the form of a list of factors to be taken into account when considering an application for a stay) conferred on Australian courts may be equally abused and result in similar outcomes as those which are occurring under the clearly inappropriate test under Voth.

Finally Spiliada itself has been subjected to vehement criticism in some academic circles, it being noted that the test for a stay under Spiliada provides for “....judicial discretion so broad and so vaguely circumscribed as to amount to an "instinctive process". ${ }^{197}$ This clearly impacts on commercial certainty and the ability of the parties to predict where their dispute will be heard (in the absence of a choice of court agreement in the case of commercial contractual disputes). Conversely it also allows the court to react to the facts of individual cases, and provide a fairer outcome when deciding the issue of forum. This criticism therefore references the competing interests of the common law to, on the one hand, create legal certainty based on a precedent-based system, and on the other, retain sufficient discretion so as ensure that fairness may be achieved in individual cases. ${ }^{198}$

Cleary this is a matter of balance and where that balance should be drawn will necessarily be contextual. In the present case however there is a good argument that the test under Voth creates certain if not just outcomes (i.e. proceedings will generally be retained in Australia), whereas the test under Spiliada is less certain but has greater capacity to create a fair outcome in specific fact scenarios. Or put another way, certainty of outcome under Voth is traded for fairness towards one of the parties. In terms of reform, s 19 is clearly more aligned with the test in Spiliada so these criticisms may equally be levelled at that test also. Ultimately a discussion between both governments about which approach is better suited to the unique

\footnotetext{
${ }^{196}$ The problem under the TTPA is that it fails to apply at the jurisdictional stage, but does when it comes to enforcement. This lacuna means the foreign defendant is then subjected to Australia's private international law. ${ }^{197}$ D W Roberson "Forum Non Conveniens in America and England: 'A Rather Fantastic Fiction"” (1987) 103 LQR 398, 414.

${ }^{198}$ Gray, above n 39, at 204.
} 
social, commercial, and legal environment of the common market needs to be carried out, with reference to wider considerations such as the interests of non-market defendants as well. This wider discussion seems to have been absent leading up to the inception of the TTPA scheme, as evidenced from the background public documentation available. ${ }^{199}$

D Remove Judgments Against Foreign Defendants from the TTPA

The better approach would appear to be to remove the ability of the plaintiff to enforce the judgments obtained against non-market residents under the TTPA altogether, and require them to be enforced in New Zealand at common law or under the Reciprocal Enforcement of Judgments Act 1934. This would ameliorate the key concern the foreign defendant has under the outer world problem (ease of enforcement of the Australian judgment in New Zealand, based on excessive jurisdiction), and would avoid other issues such as reforming the TransTasman Proceedings Act 2010 (Cth), s 19, to apply to non-common market defendants or determining what is the most appropriate test to be applied in common market cases in stay applications. Although this would not remove the issues around bias in Australian private international law, it would likely mean that judgments against foreign defendants rendered under Australian jurisdictional rules (including the test in Voth) would be unenforceable in New Zealand at common law or under the Reciprocal Enforcement of Judgments Act 1934. ${ }^{200}$ This addresses the key concern of enforcement for the foreign defendant, albeit it potentially fails to address concerns the state might have in removing this advantage for the plaintiff. ${ }^{201}$

\footnotetext{
${ }^{199}$ See footnote 29.

${ }^{200}$ Generally at common law or under the Act, "jurisdiction" for the purposes of enforcement of a foreign judgment in New Zealand requires the defendant in the original court proceedings to have either been served within the jurisdiction or to have submitted it to it via appearance which constitutes submission to the jurisdiction of the court (e.g. filing documents for the purpose of defending the substantive proceedings, as opposed to merely appearing for the purpose of applying for a stay, or submitting to the jurisdiction of the relevant courts through a non-exclusive choice of court agreement). Under Australian court rules (see footnotes ...) and the test for a stay in Voth, generally jurisdiction will be established where the case falls within the categories which allow for out of jurisdiction service without leave (e.g. the contract was entered into in Australia) or the court grants leave for service, and the Australian court determines it is not a "clearly inappropriate" forum to hear the dispute. Consequently in many cases where an Australian court has jurisdiction to hear the dispute, such cases will correspondingly not satisfy the enforcement requirements under New Zealand common law or the Reciprocal Enforcement of Judgments Act 1934 because of lack of jurisdiction within the meaning of those schemes (see Goddard and McLachlan, above $\mathrm{n} 25$, at 68-88). ${ }^{201}$ See footnote 162.
} 
E Choice of Court Agreements

In the case of choice of court agreements, it is suggested that the best approach is for both Australia and New Zealand to ratify and incorporate the Hague Convention on Choice of Court Agreements. This would remove the unfairness in terms of the current approach Australian courts take to exclusive choice of court agreements, and align (to a large extent), ${ }^{202}$ Australia's private international law with the TTPA scheme which has expressly adopted the Hague Convention approach of primacy to the parties choice of court agreement. ${ }^{203}$ This would mean any judgment resulting from an Australian decision on the enforcement of a choice of court agreement would be based on principles of private ordering and holding the parties to their bargain, as opposed to the current practice in Australia, which is paternalism and protecting the interests of local residents over those of foreign defendants. Heavily circumscribing the discretion Australian courts have under their current private international law would heavily mitigate issues of unfairness to the defendant, such as discriminatory treatment when it comes to releasing them from an Australian choice of court clause, or ensuring that they are not subjected to enforcement in New Zealand where it has been expressly agreed that a foreign court should have exclusive jurisdiction over the dispute. $^{204}$

F Conclusion

Australia's private international law (the applicable law where the case involves a foreign defendant), combined with the current TTPA regime creates the paradigm outer world problem present under other common market arrangements. Generally Australian courts will be more willing to retain proceedings commenced in the jurisdiction (even in breach of a choice of court clause), with the potential to pass judgment, which then becomes readily enforceable in both Australia and New Zealand. Depending on whose perspective this is looked at from, materially influences whether the outer world problem is a "problem" in the

\footnotetext{
202 There are some differences between the Hague Convention and the wording of the TTPA scheme (e.g. see Trans-Tasman Proceedings Act 2010 (Cth), s 20), see footnote 161).

${ }^{203}$ See footnote 161.

${ }^{204}$ See footnotes $98-125$.
} 
sense that reform is justified. The foreign defendant's perspective would appear to be the more compelling one when compared to the plaintiff's view, as the TTPA scheme is both discriminatory and dismissive of the defendant's interests when it comes to the issue of enforcing the resulting judgment in Australia. In contrast the plaintiff is effectively forum shopping, and in the cases where it has been identified unfairness does arise for the defendant (e.g. where the dispute has a close connection with another forum) it does not seem unreasonable to require the plaintiff to litigate in a forum which is more closely connected with the dispute. To a large extent the outer world problem remains present under the TTPA scheme even where there is an exclusive choice of court clause present under a commercial contract dispute (albeit the TTPA appears to fail to address issues with reference to nonexclusive choice of court clauses). So does the unfairness for the foreign defendant in these circumstances.

The more difficult question appears to be that of reform, namely which approach is best to ameliorate the unfairness which arises from allowing an Australian judgment obtained under its excessive jurisdiction to be quickly enforced in New Zealand, and even if reform is justified merely because the outer world problem is unfair on the defendant. The better approach would appear to be to remove judgments against non-common market residents from the expedited enforcement regime under the TTPA, and for Australia and New Zealand to ratify the Hague Convention on Choice of Court Agreements. Whether the issue identified in this paper will garner sufficient interest from academics and other interested parties to encourage reform yet remains unclear. Additionally there is a possibility that the scenario where the outer world problem is present may never occur in the form of a litigated case or reported decision. ${ }^{205}$ As Mortensen notes, arguably the outer world problem under the TTPA scheme is a less significant issue from an international perspective (as compared to other more significant common market arrangements such as the European Union Brussels model, where the outer world problem is also an issue). ${ }^{206}$ Nevertheless it is just as objectionable on the grounds of principle. At the very least further discussion around the potential for the problem to arise should have occurred prior to the inception of the Christchurch Agreement and the incorporating legislation - this is the least that non-common market defendants deserved.

\footnotetext{
205 See footnote 163.

${ }^{206}$ Mortensen, above n 2, at 91.
} 


\section{Bibliography}

\section{A Cases}

$1 \quad$ New Zealand

Abe v Azim HC Auckland CIV 2010-40403741, 4 April 2011

Air Nauru v Niue Air Lines Ltd [1993] 2 NZLR 632 (HC)

Black v Taylor [1993] 3 NZLR 403 (CA)

Bomac Laboratories Ltd v Life Medicals (MSDN BHD) [2012] NZHC 363

Bramwell v The Pacific Lumber Co Ltd (1986) 1 PRNZ 307 (HC)

Dymock v Bilbie (1999) 13 PRNZ 158 (HC)

Hunt v BP Exploration Company (Libya) Ltd [1980] 1 NZLR 104 (HC)

Longbeach Holdings Ltd v Bhanabhai \& Company Ltd CA Wellington CA11/93 6 Dec 1993

Lane v Questnet Ltd [2010] NZAR 210 (HC)

Marine Services Ltd v Bolton (1992) 6 PRNZ 173 (HC)

Reeves v OneWorld Challenge [2006] 2 NZLR 184 (HC)

Society of Lloyd's \& Oxford Members' Agency Ltd v Hyslop [1993] 3 NZLR 135 (HC)

Wing Hung Printing Co Ltd v Saito Offshore Pty Ltd [2010] NZCA 502, [2011] 1 NZLR 754

$2 \quad$ Australia

Akai Pty Ltd v People's Insurance Co Ltd 188 CLR 418 (HCA)

Al-Ru Farm Pty Ltd v Hedleys Humpers Ltd SASC, 10 January 1991

Banque Paribas v Jarrett SC, 25 July 1991

Band B (Re Jurisdiction) [2003] FamCA 105

Contractors Ltd v MTE Control Gear Ltd [1964] SASR 47 (SC)

Dow Jones \& Company Inc v Gutnick (2002) 210 CLR 575 
Ellwood v Federal Commissioner of Taxation [2012] AATA 869

Gem Plastics v Satrex Maritime SC, 9 June 1995

Henry v Henry (1995) 185 CLR 571

Hopkins v Difrex Societe Anonyme [1966] 1 NSWR 979 (NSWSC)

Huddart Parker v The Ship the Mill Hill (1950) 81 CLR 502

James Hardie \& Co Pty Ltd v Barry [2000] NSWCA 353

James Hardie \& Co Pty Ltd v Bruce [1996] NSWDDT 6

James Hardie \& Co Pty Ltd v Cameron [1995] NSWDDT 5

James Hardie and Co Limited v Coyle [1998] NSWSC 190

James Hardie Industries Pty Ltd v Grigor (1998) 45 NSWLR 20

Kingston Estate Wines Pty Ltd v Vetreria Etrusca Srl [2007] SADC 102

Lep International v Atlanttrafic Express Service (1987) 10 NSWLR 614 (NSWSC)

Lewis Construction v Tichauer [1966] VR 341 (VSC).

Oceanic Sun Line Special Shipping Co Inc v Fay (1988) 165 CLR 197 (HCA)

Phosphate Co-operative Company of Australia Ltd v SGS Supervision Services Inc SC 7 April 1993.

Prebble v Australian Broadcasting Corporation SC, 6 September 1996

Putt v James Hardie \& Co Pty Ltd [1998] NSWDDT 1

Puttick v Teon Limited (2008) 238 CLR 265

Re Featherston [2014] NSWSC 1139

Regie National des Usines Renault SA v Zhang (2010) 210 CLR 575 (HCA)

Union Shipping New Zealand Ltd v Morgan [2002] NSWCA 124

Voth v Manildra Flour Mills Pty Ltd (1990) 171 CLR 538 (HCA)

Woolworths v D S McMillan SC, 29 February 1988 
$3 \quad$ England

Barclays Bank Ltd v Piacun [1984] 2 Qd R 476

British South Africa Co v Companhia de Moçambique [1893] AC 602 (HL)

Owners of Cargo Lately Laden on Board Ship or Vessel Eleftheria v The Eleftheria (Owners) [1969] 2 WLR 1073

Phrantes v Argenti [1960] 2 QB 19

Smith Kline \& French Laboratories Ltd v Bloch [1983] 2 All ER 72 at 74 (CA)

Spiliada Maritime Corporation v Cansulex Ltd [1987] 1 AC 460 (HL)

The Abidin Daver [1984] 1 AC 398 (HL)

The Atlantic Star [1973] 1 QB 364

The Eleftheria [1970] p 94

\section{B Legislation}

$1 \quad$ New Zealand

i $\quad$ Statutes

Companies Act 1993

District Court Act 1947

Illegal Contract Act 1970

Judicature Act 1908

Reciprocal Enforcement of Judgments Act 1934

Trans-Tasman Proceedings Act 2010 (NZ).

ii Subordinate Legislation

District Court Rules 2014

High Court Rules 2009 
Trans-Tasman Proceedings Regulations and Rules 2013

$2 \quad$ Australia

i $\quad$ Statutes

Service and Execution of Process Act 1992 (Cth)

Trans-Tasman Proceedings Act 2010 (Cth).

$3 \quad$ England

i Statutes

Civil Jurisdiction and Judgments Act 1982

$4 \quad$ European Union

Regulation 44/2001 on jurisdiction and the recognition and enforcement of judgments in civil and commercial matters [2001] OJ L012.

\section{International Treaties}

Agreement between the Government of Australia and the Government of New Zealand on Trans-Tasman Court Proceedings and Regulatory Enforcement (done at Christchurch 24 July 2008)

Convention on Choice of Court Agreements 2005 (done at The Hague 30 June 2005)

International Covenant on Civil and Political Rights GA Res 2200A XXI (1966)

\section{Books}

Andrew S Bell Forum Shopping and Venue in Transnational Litigation (Oxford University Press, Oxford, 2003)

Ronald A Brand and Paul M Herrup The 2005 Hague Convention on Choice of Court Agreements (Cambridge University Press, 2008)

A Briggs and P Rees Civil Jurisdiction and Judgments (2nd ed, LLP, 1997)

A Briggs and P Rees, Civil Jurisdiction and Judgments (5th ed, Informa Law, 2009)

Bernard Cairns, Australian Civil Procedure (10th ed, Thomas Reuters, Sydney, 2014) 
L Collins Dicey Morris \& Collins on the Conflict of Laws (15th ed, Sweet \& Maxwell, London, 2012)

RA Brand and SR Jablonski, Forum Non Conveniens: History, Global Practice, and Future Under the Hague Convention on Choice of Court Agreements (Oxford University Press, 2007)

\section{E Journal Articles}

Ardavan Arzandeh "Should the Spiliada Test be Revised" (2014) 10 J Priv Int L 89

J L R Davis “Closer Economic Relations - A Trans-Tasman Confederation?” (2010) 16 Canta LR 47

R Garnett, "Stay of Proceedings in Australia: A "Clearly Inappropriate” Test (1999) 23 MULR 30

R Garnett, “The Enforcement of Jurisdiction Clauses” (1998) 21 UNSWLJ 1

Anthony Gray "Forum Non Conveniens in Australia: A Comparative Analysis" (2009) 38 CLWR 207

F K Juenger "What's Wrong With Forum Shopping” (1994) 16 Syd LR 1

Michael Karayanni "The Myth and Reality of a Controversy: "Public Factors" and the Forum Non Conveniens Doctrine” (2003) Wisconsin Int'1 LJ 327

M Keyes "Jurisdiction under the Hague Choice of Courts Convention: Its Likely Impact on Australian Practice” (2009) 5 J Priv Int L 181

Reid Mortensen "A Trans-Tasman Judicial Area: Civil Jurisdiction and Judgments in the Single Economic Market" (2010) 16 Canta LR 61

Reid Mortensen, “Autochthonous Essential: State Courts and a Cooperative National Scheme of Civil Jurisdiction" (2003) 22 U Tas LR 109

Brian R Opeskin “The Price of Forum Shopping: A Reply to Professor Juenger” (1994) 16 Syd LR 14 
M Pryles and FA Trindade "The Common Market (EEC) Convention on Jurisdiction and Enforcement of Judgments in Civil and Commercial Matters - Possible Impact Upon Australian Citizens" (1974) 48 ALJ 185

K Nadelmann "The Outer World and the Common Market Experts' Draft Convention on the Recognition of Judgments" (1968) 5 CML Rev 409

K Nadelmann "Clouds Over International Efforts to Unify Rules of Conflicts of Laws" (1977) 41 LCP 54

D W Roberson "Forum Non Conveniens in America and England: 'A Rather Fantastic Fiction"” (1987) 103 LQR 398

\section{E Seminar Presentations}

David Goddard QC and Campbell McLaughlan QC "Private International Law - litigating in the trans-Tasman context and beyond" (paper presented to NZLS CLE conference, August 2012)

\section{F Government Publications}

$1 \quad$ New Zealand Parliamentary Material

Trans-Tasman Proceedings Bill 105-2 (select-committee report)

(23 March 2010) 661 NZPD 9702

$2 \quad$ Australian Parliamentary Material

(18 March 2010) CAPD 2215 (Cth)

$3 \quad$ Australia and New Zealand

Trans-Tasman Working Group, Trans-Tasman Court Proceedings and Regulatory Enforcement: A Public Discussion Paper by the Trans-Tasman Working Group (Attorney General's Department (Australia) Ministry of Justice (New Zealand), August 2005)

Trans-Tasman Working Group, Trans-Tasman Court Proceedings and Regulatory Enforcement: A Report by the Trans-Tasman Working Group (Ministry of Justice, December 2006) 
VII Word Count

The text of this paper (excluding cover page, non-substantive footnotes, discussion questions and bibliography) comprises approximately 15,000 words. 